\title{
Histological, ultrastructural, and biochemical study on the possible role of Panax ginseng in ameliorating liver injury induced by Lambda cyhalotherin
}

\author{
Manal Abdul-Hamid ${ }^{*}$, Hanaa M. Mohamed, Sanaa M. Abd El-Twab and Karim Zaied
}

\begin{abstract}
Background: Lambda-cyhalotherin (LCT) is a pyrithroid type 2 pesticide that is broadly utilized in pest control in public health, animal health, and agriculture. Although claiming that LCT has a low mammalian toxicity, several investigations reported its mammalian hepatotoxicity by mediating oxidative stress causes severe hepatotoxicity and liver damage.

Results: LCT significantly decreased catalase (CAT), superoxide dismutase (SOD), and total thiol (T. thiol) and increased lipid peroxidation (LPO). mRNA and protein expression levels of p53 were upregulated, whereas Bcl-2 mRNA and protein expression levels were downregulated in LCT-intoxicated animals. Also, light microscopic and ultrastructure studies for liver tissues of LCT-intoxicated animals showed mononuclear leukocytic infiltration in the parenchyma, congested portal vein with thickened wall, and proliferation of bile duct and hepatocytes with cytoplasmic vacuolations, fatty changes, and collagen fibers. Panax ginseng co-treatment attenuated oxidative stress biomarkers. Both tested doses of Panax ginseng (100 and $200 \mathrm{mg} / \mathrm{kg}$ b. wt./day) significantly decreased p53 and elevate Bcl-2 mRNA and protein expression levels and reveals significant amelioration and restoration of normal histology and ultrastructure of liver, but $200 \mathrm{mg} / \mathrm{kg} \mathrm{b.} \mathrm{wt.} \mathrm{of} \mathrm{Panax} \mathrm{ginseng} \mathrm{seems} \mathrm{to} \mathrm{be} \mathrm{more} \mathrm{potent.}$

Conclusion: Panax ginseng exhibited ameliorative effect against hepatic oxidative stress, apoptosis, histopathological, and ultrastructural changes induced by LCT.
\end{abstract}

Keywords: Lambda-cyhalothrin, Panax ginseng, Antioxidants enzyme activities, p53, Bcl-2, Histopathology and ultrastructure of liver

\section{Background}

Pesticides are among the most environmental pollutant chemicals and their indiscriminate usage is growing [1]. Pyrethroids are a group of greater than 1000 strong wide range pesticides [2] presenting approximately $25 \%$ of the worldwide insecticide market [3]. They are synthesized analogues of natural pyrethrins which is the active ingredient in Chrysanthemum, Cineraria folium, flowers [4].

\footnotetext{
*Correspondence: medo_bio@yahoo.com;

manal.mohamed3@science.bsu.edu.eg

Department of Zoology, Faculty of Science, Beni-Suef University, Beni-Suef, Egypt
}

\section{Springer Open}

According to presence of $\alpha$-cyano group, they can be divided into 2 big groups that differ in their action [5].

Lambda-cyhalotherin (LCT), type 2 pyrethroid, utilized for controlling a wide spectrum of ectoparasites mainly on sheep and cattle and to a smaller range in goats and pigs. It is also used for controlling aphids and other pests in cereals, cotton various vegetables, and fruits agriculture. Moreover, its usage in controlling mosquitoes, ticks, flies, and cockroaches that may be vectors of diseases is very important for public health management. Malaria epidemic-prone areas were sprayed with LCT to kill vectors of malaria [6, 7]. (c) The Author(s). 2020 Open Access This article is licensed under a Creative Commons Attribution 4.0 International License, which permits use, sharing, adaptation, distribution and reproduction in any medium or format, as long as you give appropriate credit to the original author(s) and the source, provide a link to the Creative Commons licence, and indicate if changes were made. The images or other third party material in this article are included in the article's Creative Commons licence, unless indicated otherwise in a credit line to the material. If material is not included in the article's Creative Commons licence and your intended use is not permitted by statutory regulation or exceeds the permitted use, you will need to obtain permission directly from the copyright holder. To view a copy of this licence, visit http://creativecommons.org/licenses/by/4.0/. 
Despite claiming that LCT has a low mammalian toxicity, several investigations reported the mammalian hepatotoxicity of LCT $[8,9]$. Numerous mechanisms were proposed as a possible justification for mammalian toxicity of pyrethoids including generation of excess reactive oxygen species (ROS) leading to oxidative damage [10]. ROS react directly with cellular biomolecules leading to lipid peroxidation (LPO), protein oxidation, and DNA damage [11] that eventually conduce to alterations in function and structure of cell [12]. El-Demerdash [13] and Fetoui et al. [14] observed that ROS are involved in LCT-induced hepatotoxicity and oxidative damages. Moreover, Fetoui et al. [15] reported that LCT induce ROS and reduced activities of antioxidant enzymes superoxide dismutase (SOD), catalase (CAT), GPx, GST, and GSH in liver leading to increase lipid peroxidation so induce destruction in structure and function of liver.

Some synthetic antioxidants that were used to avoid oxidative stress may cause side effects [16]. Thus, there is increasing interest in using natural antioxidants of plant origin to ensure safety and efficacy against oxidative stress via decelerating of ROS generation. In the Asian traditional medicine, Panax ginseng (G) is considered to be the most precious plant among medicinal herbs for the treatment of various ailments such as metabolic syndrome, hypertension, immune deficiency, respiratory, and hepatic dysfunction [17]. The most important part of $\mathrm{G}$ is the root, containing numerous active ingredients: ginsenosides (saponins), polyacetylenes, polyphenolic compounds, and acidic polysaccharides, and among the components, the most pharmaceutically active are ginsenosides [18].

The mechanisms that provide hepatoprotective effects of $\mathrm{G}$ are strongly related to its antioxidant activities. G treatment inhibited oxidative stress damage such as lipid peroxidation [19], alanine aminotransferase (ALT), aspartate aminotransferase (AST), and lactate dehydrogenase $(\mathrm{LDH})$ [20]. Also, $\mathrm{G}$ improved the antioxidant defense mechanism [21] and elevated self-antioxidant enzyme activities of SOD, CAT, GPx, GR, GSH, and heme oxygenase-1 in the aged-rat liver [19] and hepatotoxins-induced liver damages in rats [22]. With this background, G with its antioxidant properties is among possible research targets for its promising advantage to be used in alleviating LCT toxicity. Thus the current study was undertaken to define the possible ameliorative effects of G against LCT-induced hepatic damage via oxidative stress, apoptosis, histopathological, and ultrastructural changes in liver of adult albino rats.

\section{Methods}

\subsection{Chemicals}

Lambda-cyhalothrin (LCT), purchased from Pharmacure for Chemicals and Pharmaceuticals, Egypt with commercial name Lambda C 5\%. Pure ginseng was purchased from PHARCO Pharmaceutical Industries (Cairo, Egypt). All chemicals with analytical quality and were obtained from standard commercial products.

\subsection{Animals and experimental design}

Thirty-six male adult laboratory rats (Rattus norvegicus domestica), which weighed around $135 \pm 10$ g. They were collected from the National Research Center (NRC), Doki, Giza, Egypt and kept under observation to exclude any intercurrent infection for 14 days before the start of the experiment. The animals selected were kept in plastic cages with good aeration at temperature $(25 \pm$ $5{ }^{\circ} \mathrm{C}$ ), normal dark/light cycle of $12 \mathrm{~h}$, and humidity (55 $\pm 5 \%$ ). The rats were supplied with known composition basal diet and water ad libitum throughout study time. In this study, animal care was carried out following the European Community Directive (86/609/EEC) and national rules, this is in accordance with the NIH Guidelines for care and use of Laboratory Animals, $8^{\text {th }}$ editions. This was administrated by the committee of the Zoology Department, Beni-Seuf University, Egypt. At the end of experiment, the rats were sacrificed by anesthesia inhalation under light diethyl ether (5\%).

Six groups of rats (6 per group) were separated randomly as follows:

Group 1 (C, control): rats received normal saline through intraperitoneal (i.p.) injection daily for 60 days. Group 2 (G 100): rats received G at a daily dose of 100 $\mathrm{mg} / \mathrm{kg}$ b. wt. dissolved in normal saline [23] by i.p. injection for 60 days.

Group 3 (G 200): rats received G at a daily dose of 200 $\mathrm{mg} / \mathrm{kg}$ b. wt. [24] by i.p. injection for 60 days.

Group 4 (LCT): rats received LCT at a daily dose of $61.2 \mathrm{mg} / \mathrm{kg}$ b. wt. (1/10 of LD50) [25] by oral gavage for 60 days.

Group 5 (LCT + 100): rats received the same dose of LCT, as in group 4, followed immediately by G, as in group 2, daily for 60 days.

Group $6(\mathrm{LCT}+200)$ : rats received the same dose of LCT, as in group 4, followed immediately by G, as in group 3, daily for 60 days.

The doses were adjusted weekly regarding to body weight changes to sustain comparable dose per $\mathrm{kg}$ rat's body weight till the end of experiment period.

\subsection{Samples preparation}

Body weight change was determined from the gap between the initial weight at the beginning and the final weight upon completion of study. Before weight recoding, all rats were fasted for $10 \mathrm{~h}$ (water ad libitum) to exclude feeding error. All groups of rats are sacrificed 
Table 1 Primer pairs used for qPCR

\begin{tabular}{lll}
\hline & Primer sequence & Gene bank accessi-on number \\
\hline P53 & Forward primer: 5'-GAGCTGAATGAGGCCTTGGA-3' & NM_022112 \\
& Reverse primer: 5'-CTGAGTCAGGCC CTTCTGTCT T-3' & NM009741 \\
BCl-2 & Forward primer: 5'-CCT GTG GAT GAC TGA GTA CC-3' & \\
& Reverse primer: 5'-GAG ACA GCC AGG AGA AAT CA-3' & XM_017593963.1 \\
Beta actin & Forward primer: 5'-GGTCGGTGTGAACGGATTTGG-3' & \\
& Reverse primer: 5'-ATGTAGGCCATGAGGTCCACC-3' & \\
\hline
\end{tabular}

under anesthesia of diethyl ether at the end of the 2 months. Liver were rapidly taken out, washed with icecold saline, and splitted into 3 parts. The first was the liver part $(10 \% \mathrm{w} / \mathrm{v})$ which was homogenized using Teflon tissue homogenizer (Omni International Inc., Kennesaw, GA, USA) in phosphate-buffered saline (PBS), then for $10 \mathrm{~min}$ using centrifuge at $3000 \mathrm{rpm}$ the clear homogenates were obtained and frozen at $-80{ }^{\circ} \mathrm{C}$ for subsequent analysis of oxidative stress parameters; the second part was kept frozen at $-80{ }^{\circ} \mathrm{C}$ for gene and protein expression analysis. The third part was used for electron and light microscopic examination.

\subsection{Biochemical assays}

\subsubsection{Assay of serum biochemical}

For serum, the activities of alanine transaminase (ALT) and aspartate transaminase (AST) were spectrophotometrically determined using the methods of Schumann and Klauke [26]. Also, alkaline phosphatase (ALP) activity was estimated by spectrophotometer using the methods of Wenger et al. [27] and Rosalki et al. [28].

\subsubsection{Assay of oxidative stress and antioxidant defense system}

For liver homogenates, LPO content was calculated by measuring malondialdehyde (MDA) content using the Preuss et al. [29] method. Total thiol (T. thiol) content and the antioxidant enzyme activities, catalase (CAT), and superoxide dismutase (SOD) were estimated using the methods of Koster et al. [30], Cohen et al. [31], and Marklund and Marklund [32], respectively.

\subsection{RNA isolation and quantitative reverse transcription polymerase chain reaction}

LCT effect on mRNA abundance of p53 and Bcl-2 was studied by qRT-PCR according to Mahmoud et al. [33]. Complementary DNAs were synthesized from $2 \mu \mathrm{g}$ RNA and were amplified using SYBR Green master mix (Thermo Fisher Scientific, USA) with the primer sets listed in Table 1. Quantitative polymerase chain reaction (qPCR) was conducted and the amplification data was analyzed by the $2-\Delta \Delta \mathrm{Ct}$ method [34]. The results were normalized to $\beta$-actin and shown as percentage of control.

\subsection{Western blot analysis}

LCT effect on p53 and Bcl-2 expression levels were evaluated from the frozen liver samples by chemiluminescence kit (BIORAD, USA) [35]. $\beta$-actin was used as a loading control.

\subsection{Light microscopic study}

Small parts of liver tissue were fixed for $24 \mathrm{~h}$ by $10 \%$ formalin-buffered phosphate. The tissue was processed, sectioned with a microtome at 4-5 $\mu \mathrm{m}$

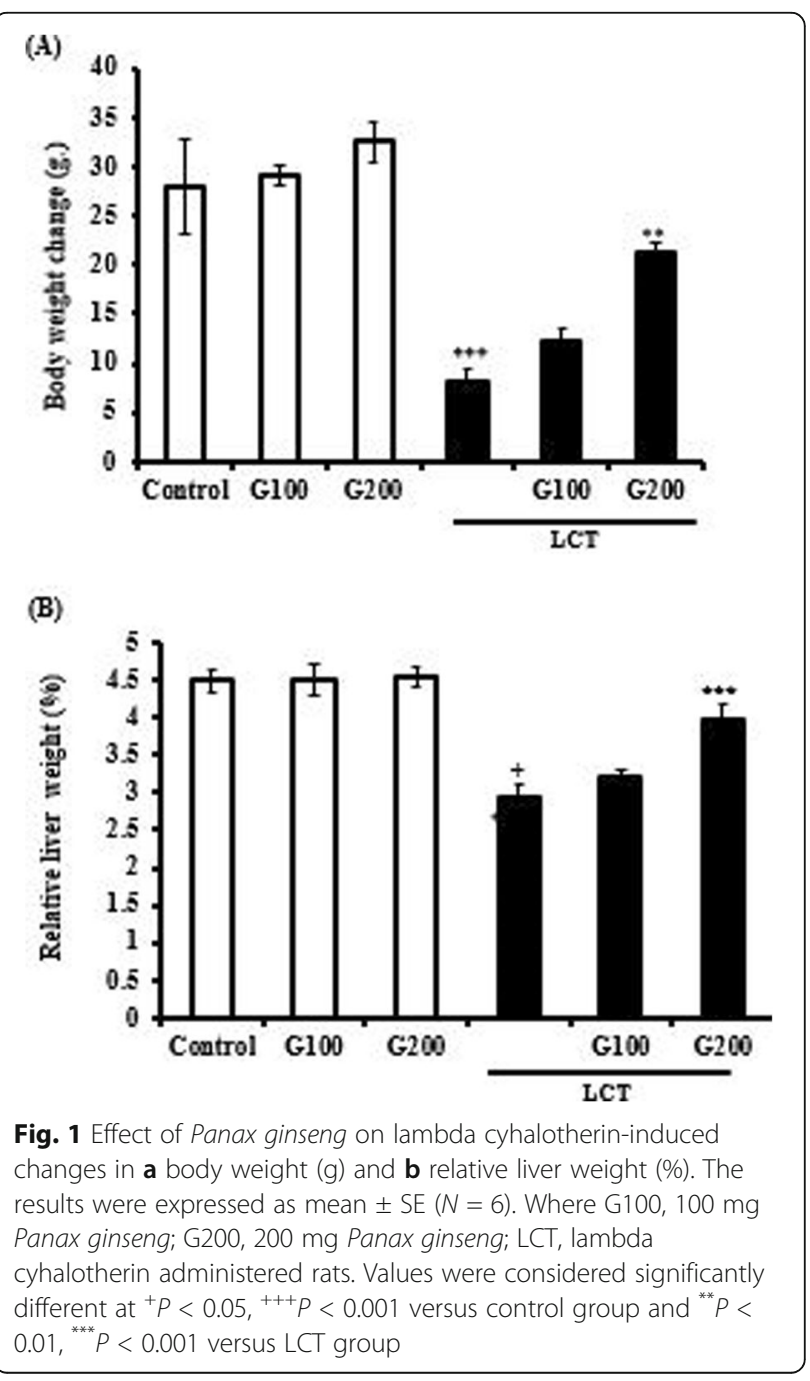



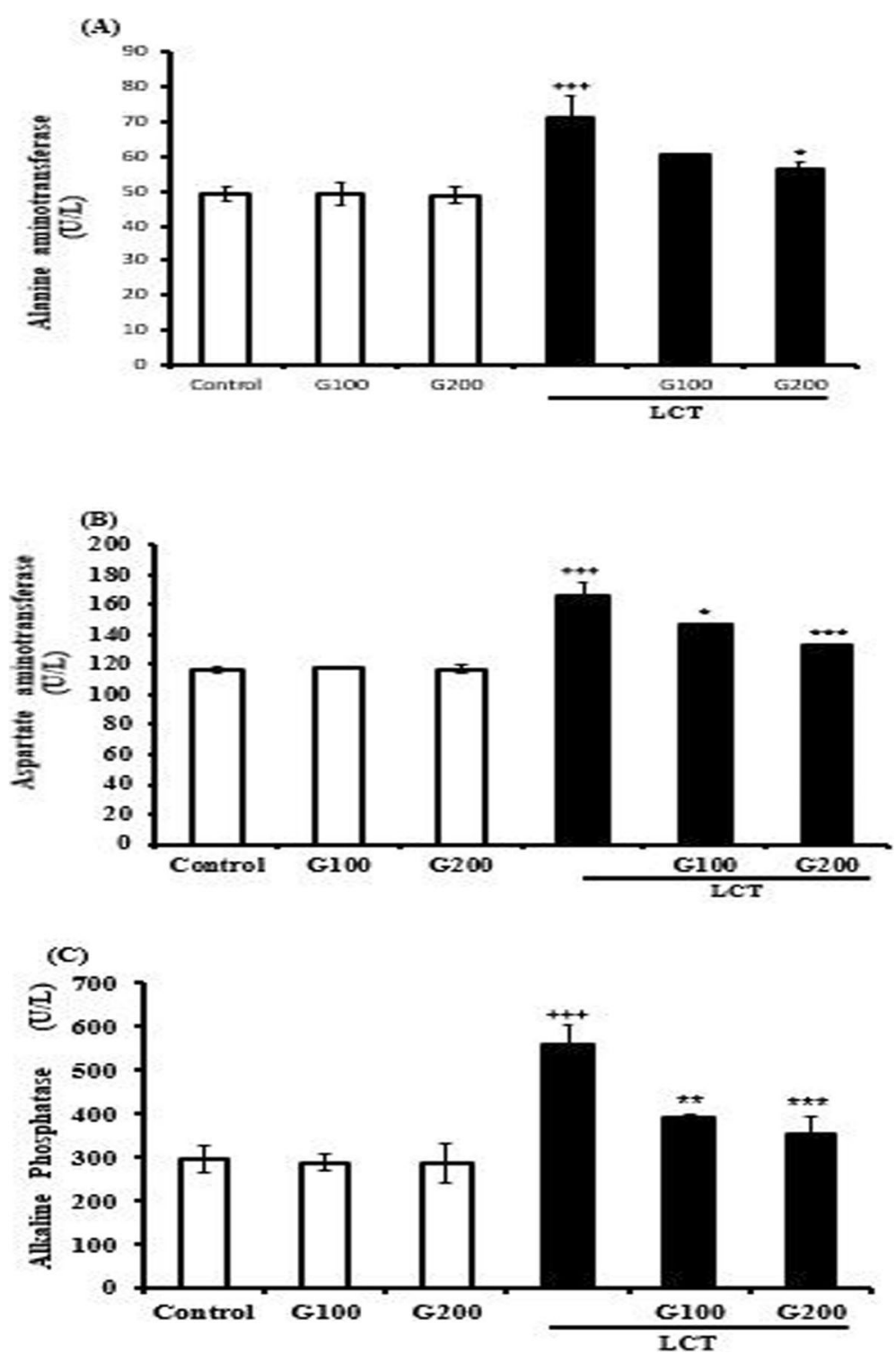

Fig. 2 Effect of Panax ginseng on lambda cyhalotherin-induced changes in a alanine aminotransferase (U/L), b aspartate aminotransferase (U/L), and $\mathbf{c}$ alkaline phosphatase (U/L). The results were expressed as mean \pm SE ( $N=6)$. Where G100, $100 \mathrm{mg}$ Panax ginseng; G200, $200 \mathrm{mg}$ Panax ginseng; $L C T$, lambda cyhalotherin administered rats. Values were considered significantly different at ${ }^{+++} P<0.001$ versus control group and ${ }^{*} P<$ $0.05,{ }^{* *} P<0.01,{ }^{* * *} P<0.001$ versus LCT group

thickness, and then treated with hematoxylin and eosin stain (H\&E) [36].

\subsection{Ultrastructural study}

Small liver portions of all groups were immediately fixed at $4{ }^{\circ} \mathrm{C}$ for $18-24 \mathrm{~h}$ in $3 \%$ glutaraldehyde-formaldehyde, washed in phosphate buffer, followed by $1 \%$ post-fixation in osmium tetroxide. In a sequence of alcohols, the specimens were then dehydrated, washed in propylene oxide, and eventually embedded in Epon epoxy resin. After that, an ultra-microtome trimmed the blocks, sectioning them with glass knives. Semi-thin sections $(1 \mathrm{~mm})$ have been treated with toluidine blue stain and examined on light microscope in order to choose the correct region for the ultrathin parts. The same ultra-microtome was used for cutting sections of ultrathin $(70-90 \mathrm{~nm})$ and then treated with uranyl acetate and lead citrate stain [37]. Joel CX 100 transmission electron microscope, operated at an accelerating voltage of $60 \mathrm{kV}$, performed an examination of the stained sections.

\subsection{Statistical analysis}

Version 20 of the Social Sciences Statistical System (SPSS) for the Windows software system (SPSS Inc, 
Chicago, IL, USA) was used for analyzing data. All statistical comparisons were created according to one-way ANOVA method accompanied by post-hoc analysis, and the results were shown as mean \pm standard error (SE). A value of $P<0.05$ was rated significant.

\section{Results}

\subsection{Effect of Panax ginseng on body weight change of LCT-intoxicated rats}

Experimental animals orally administered LCT (61.2 $\mathrm{mg} / \mathrm{kg} /$ day) for 60 exhibited a significant $(P<0.001)$ decrease in body weight change in comparison with normal control group. However, intraperitoneal injection of G $(200 \mathrm{mg} / \mathrm{kg}$ b. wt./day) caused a significant $(P<0.01)$ elevation in body weight change in comparison with LCT-intoxicated rats. While intraperitoneal injection with $100 \mathrm{mg} \mathrm{G} / \mathrm{kg}$ b. wt. daily for 60 days exhibited a non-significant $(P>0.05)$ elevation in body weight change in comparison with LCT-intoxicated rats. Body weight of control groups treated with either tested doses of $\mathrm{G}$ did not show any difference from normal control group (Fig. 1a).

\subsection{Effect of Panax ginseng on relative liver weight of LCT-intoxicated rats}

Relative liver weight exhibited a significant $(P<0.05)$ decrease in LCT-treated rats in comparison with normal control group. Intraperitoneal injection of G $(200 \mathrm{mg} / \mathrm{kg}$ b. wt./day) caused a significant $(P<0.001)$ elevation in relative liver weight in comparison with LCT-treated rats. While intraperitoneal injection with $100 \mathrm{mg} \mathrm{G} / \mathrm{kg}$ b. wt. daily for 60 days exhibited a non-significant $(P>$ $0.05)$ increase in relative liver body weight (Fig. 1b).

\subsection{Effect of Panax ginseng on liver function of LCT- intoxicated rats}

Both of alanine aminotransferase (ALT) and aspartate aminotransferase (AST) exhibited a significant $(P<$ 0.001 ) increased activity in serum of LCT-treated rats in comparison with control group. Intraperitoneal injection of G $(200 \mathrm{mg} / \mathrm{kg}$ b. wt./day) caused a significant $(P<$ $0.05)$ decrease in ALT activity and a significant reduction in AST activity when compared to LCT-intoxicated rats. While intraperitoneal injection with $100 \mathrm{mg} \mathrm{G} / \mathrm{kg}$ b. wt. daily for 60 days showed a non-significant $(P>$ $0.05)$ decrease of ALT activity and a significant $(P<$ 0.05) decrease in AST activity (Fig. 2a, b).

Alkaline phosphatase (ALP) showed the same behavioral pattern as ALT and AST. It was significantly $(P<0.001)$ elevated in serum of LCT-administered rats and decreased as a result of $\mathrm{G}$ administration. However, $200 \mathrm{mg} \mathrm{G}$ seemed to be more effective $(P<0.001)$ than $100 \mathrm{mg} \mathrm{G}(P<0.01)$ in decreasing serum ALP activity (Fig. 2c).

\subsection{Effect of Panax ginseng on liver LPO and T. thiol} content of LCT intoxicated rats

As elucidated in Fig. 3a, liver lipid peroxidation (LPO), estimated as nmol malondialdehyde (MDA)/100 mg tissue, exhibited a significant $(P<0.001)$ elevation in LCTtreated rats in comparison with normal control group. According to the administered dose of G, There is a varying significance in MDA level decrease. Intraperitoneal injection of G (200 mg/kg b. wt./day) showed a significant $(P<0.05)$ reduction in MDA levels. While intraperitoneal injection with $100 \mathrm{mg} \mathrm{G} / \mathrm{kg}$ b. wt. daily for 60 days showed a non-significant $(P>0.05)$ decrease in MDA level (Fig. 3a).

LCT-intoxicated rats showed a significant $(P<0.001)$ reduction of liver $\mathrm{T}$. thiol contents in comparison with normal control group. However, intraperitoneal injection of $100 \mathrm{mg} \mathrm{G} / \mathrm{kg} \mathrm{b}$. wt. for 60 days produced a nonsignificant $(P>0.05)$ elevation in $\mathrm{T}$. thiol content in comparison with LCT-intoxicated group. While

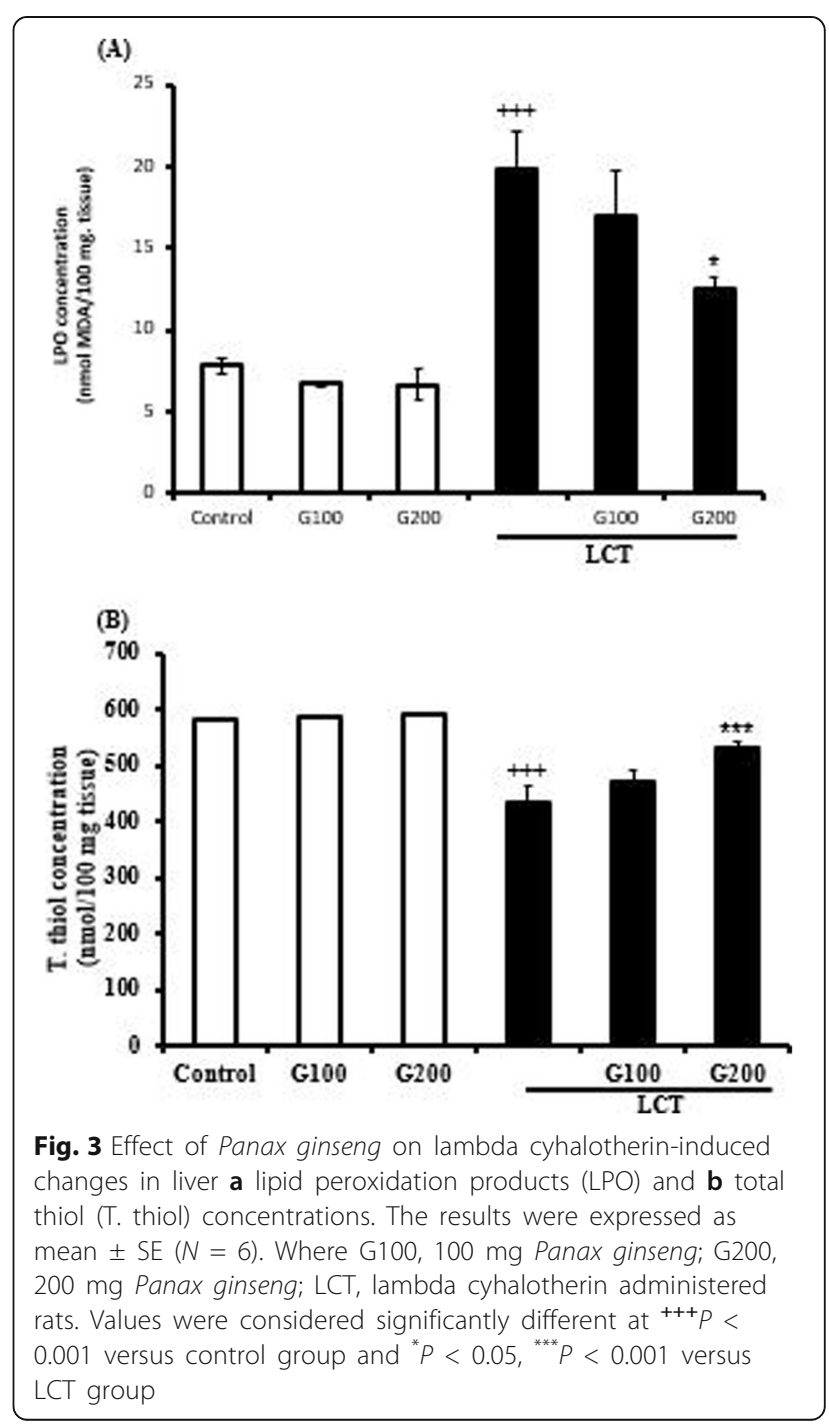


treatment with $200 \mathrm{mg} \mathrm{G} / \mathrm{kg} /$ day significantly $(P<$ $0.001)$ increased hepatic total thiol level when compared to LCT-intoxicated rats as shown in (Fig. 3b).

\subsection{Effect of Panax ginseng on liver superoxide dismutase} (SOD) and catalase (CAT) activities of LCT-intoxicated rats Figure 4 shows the effect of LCT administration on liver SOD and CAT activities. The data recorded obviously showed a significant $(P<0.001)$ reduction in both CAT and SOD activities in LCT-administered group in comparison with control rats. Along concurrent injection with LCT, G elevated the activities of CAT with varying significance. However, $200 \mathrm{mg} \mathrm{G}$ seemed to be more effective $(P<0.001)$ than $100 \mathrm{mg} \mathrm{G}(P<0.01)$ in increasing the activities of CAT (Fig. 4b). Regarding SOD (Fig. 4a), only $200 \mathrm{mg}$ produced a significant $(P<0.05)$ increase in liver SOD activity while $100 \mathrm{mg}$ produced a non-significant $(P>0.05)$ increase.

\subsection{Effect of Panax ginseng on liver apoptotic P53 gene} and protein expression levels of LCT-intoxicated rats As shown in Fig. 5 a, mRNA expression of P53 in liver tissue of LCT-intoxicated rats exhibited a significant $(P$ $<0.001$ ) upregulation as compared to normal control group. While intraperitoneal co-injection with both tested doses of $\mathrm{G}$ induced a significant $(P<0.001)$ downregulation of P53 mRNA expression levels as compared to rats that received LCT only.

Protein expression level of apoptotic protein P53 in liver tissue of LCT-intoxicated rats showed a significant

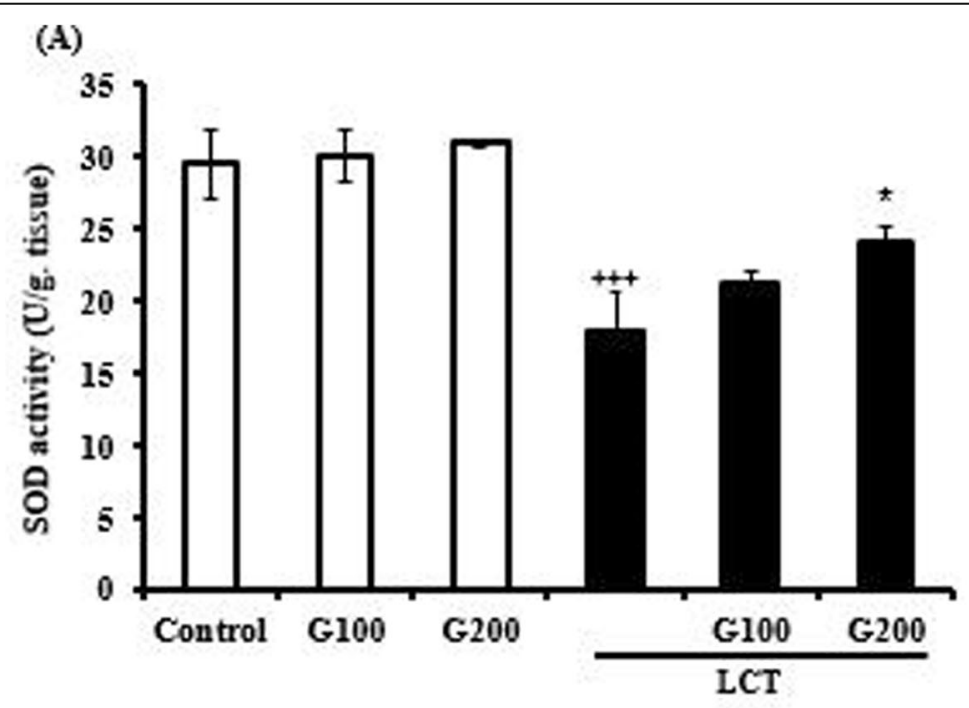

(B)

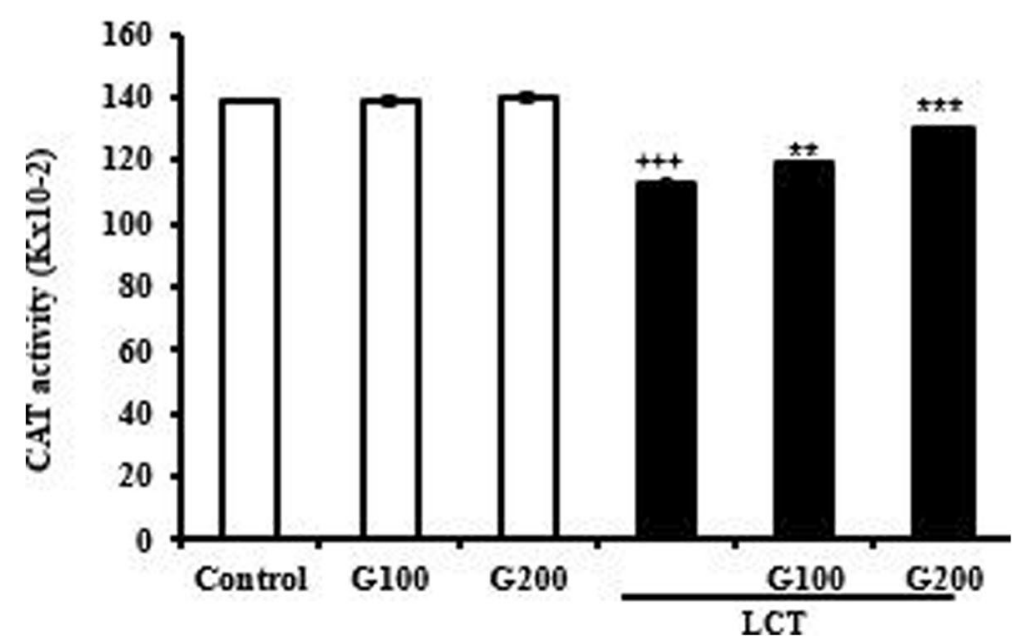

Fig. 4 Effect of Panax ginseng on lambda cyhalotherin-induced changes in liver enzymatic antioxidant defenses a superoxide dismutase (SOD) and $\mathbf{b}$ catalase (CAT) activities. The results were expressed as mean \pm SE ( $N=6)$. Where G100, $100 \mathrm{mg}$ Panax ginseng; G200, $200 \mathrm{mg}$ Panax ginseng; $L C T$, lambda cyhalotherin administered rats. Values were considered significantly different at ${ }^{+++} P<0.001$ versus control group and ${ }^{*} P<$ $0.05,{ }^{* *} P<0.01,{ }^{* * *} P<0.001$ versus LCT group 

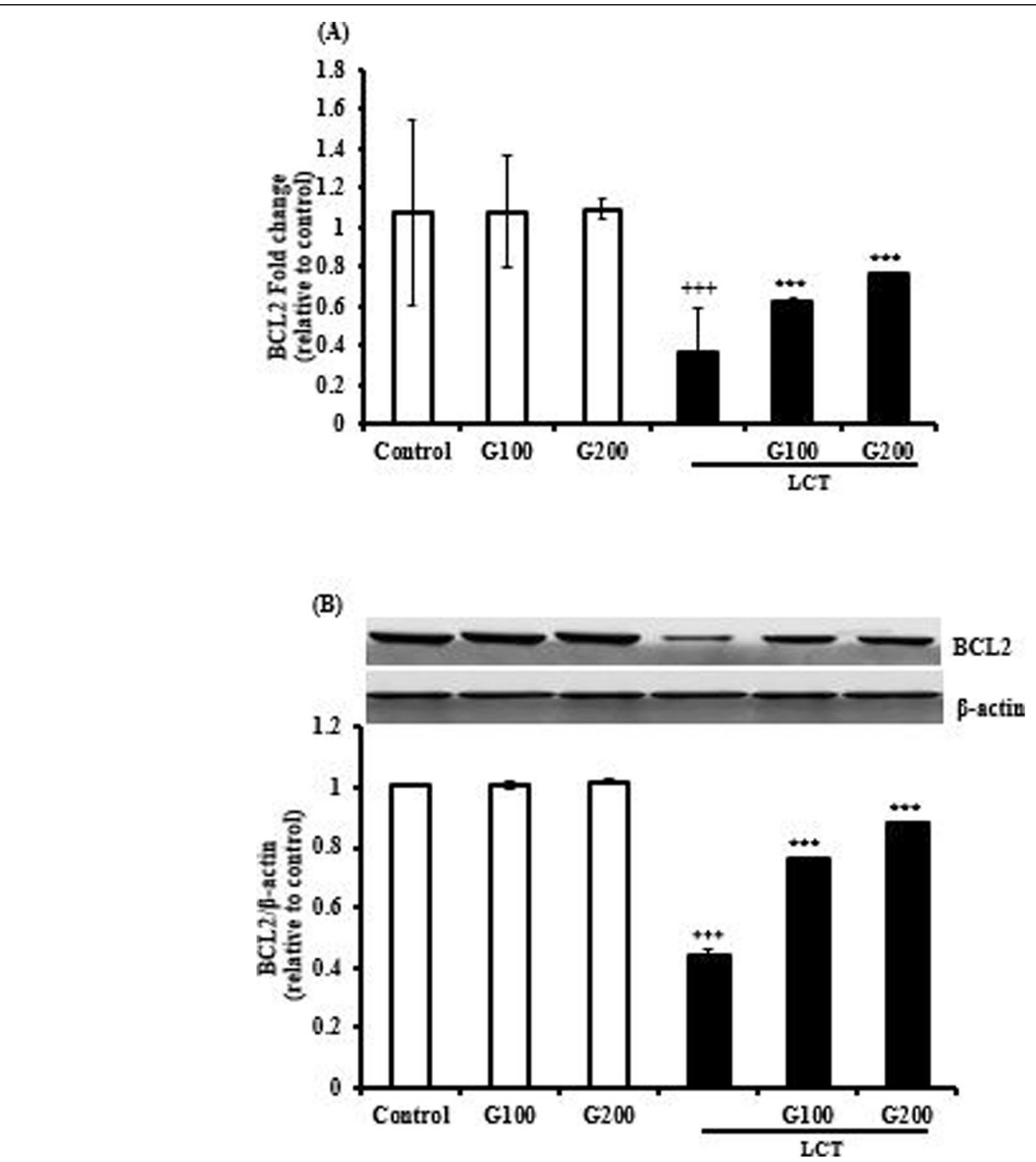

Fig. 5 Liver a $B C L 2$ mRNA and $\mathbf{b} B C L 2$ protein expression levels in control, $G, L C T$, and $L C T$ rats co-treated with $G$. The results were expressed as mean $\pm S E(N=6)$. Where $C$, control group; $G$, Panax ginseng injected rats; and $L C T$, lambda cyhalotherin administered rats. Values were considered significantly different ${ }^{+++} P<0.001$ versus control group and ${ }^{* * *} P<0.001$ versus LCT group

$(P<0.001)$ elevation in comparison with control group. Intraperitoneal injection of both tested doses of $\mathrm{G}$ concomitant with LCT produced a significant $(P<0.001)$ reduction in P53 protein expression levels in comparison with LCT-administered rats as illustrated in (Fig. 5b).

3.7 Effect of Panax ginseng on liver anti-apoptotic B cell lymphoma-2 (Bcl-2) gene and protein expression level of LCT-intoxicated rats

qPCR analysis of Bcl-2 gene expression in liver of LCTintoxicated rats exhibited a significant $(P<0.001)$ downregulation as compared to normal rats. Simultaneous administration of both tested doses of G with LCT induced a significant $(P<0.001)$ upregulation of Bcl-2 mRNA expression levels as compared to LCT-intoxicated group (Fig. 6a).

Western blotting data exhibited a significant $(P<$ 0.001) decrease in Bcl-2 protein expression level in liver tissues of LCT group as compared to the normal control group. Intraperitoneal co-injection of $\mathrm{G}$ with LCT produced a significant $(P<0.001)$ elevation in protein expression levels in comparison with LCT group (Fig. 6b).

\subsection{Effect of Panax ginseng on liver histolopathology of LCT-intoxicated rats}

The histological examination of the liver of control, G100 $\mathrm{mg} / \mathrm{kg}$ b. wt./day and G200 mg/kg b. wt./day (Fig. 7 a-c) 


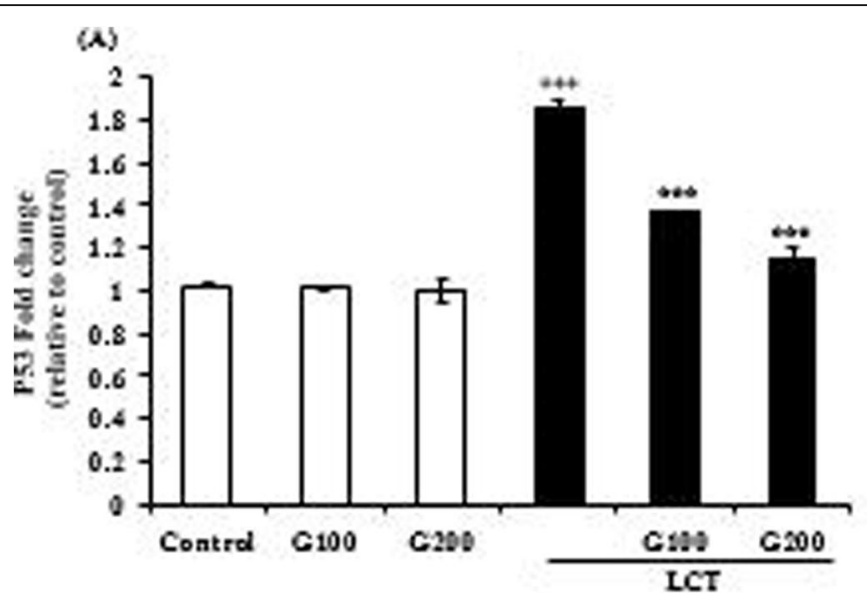

(E)

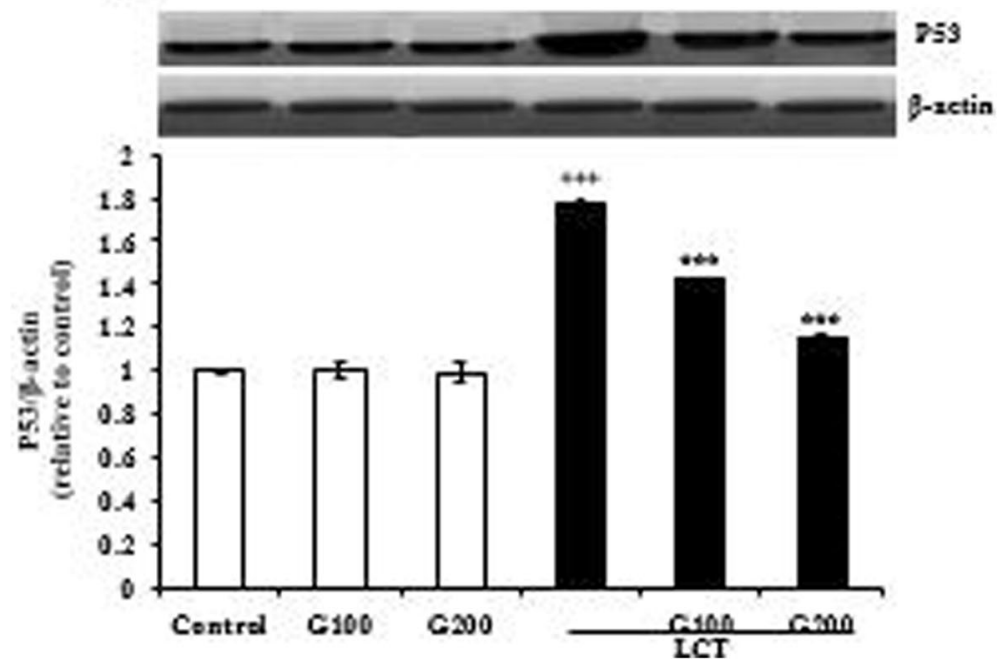

Fig. 6 Liver a P53 mRNA and b P53 protein expression levels in control, G, LCT, and LCT rats co-treated with G. The results were expressed as mean \pm SE $(N=6)$. Where $C$, control group; $G$, Panax ginseng injected rats; and $L C T$, lambda cyhalotherin administered rats. Values were considered significantly different ${ }^{+++} P<0.001$ versus control group and ${ }^{* * *} P<0.001$ versus LCT group

showed that it consists of numerous hepatic lobules; in the center of each of these hepatic lobules, there is a central vein. Each lobule is consisted of cords of hepatocytes radiating from the central vein. The cell cords are separated by narrow blood sinusoids which lined by Kupffer cells and endothelial cells. The hepatocytes are polygonal in shape with acidophilic cytoplasm and rounded darkly stained nucleus. The portal triads are distributed at the corners of the lobules and representing branches of the portal vein, hepatic artery, and bile duct.

LCT-intoxicated group showed obvious histopathological changes; these include mononuclear leukocytic infiltration in the parenchyma, congested portal vein with thickened wall, proliferation of bile duct, where some of them with hyperplastic wall, edema, and hepatocytes with hypereosinophilic cytoplasm were also detected (Fig. 8 a, b). Dilated hyperemic sinusoids, extensive vacuolar degeneration of hepatocytes, and many hepatocytes with pyknotic and karyolytic nuclei were also seen (Fig. 8 c, d). Some hepatocytes that undergo fatty change also detected (Fig. $8 \mathrm{~d}$ ).

Liver of LCT-intoxicated rat treated with G $100 \mathrm{mg} / \mathrm{kg}$ b. wt./day revealed relative recovery except some vacuolar degeneration of hepatocytes and dilated sinusoids (Fig. 9 a). Liver of LCT-intoxicated rat treated with G $200 \mathrm{mg} / \mathrm{kg} \mathrm{b}$. wt./day showed marked amelioration and restoration of normal appearance of hepatocyte and central vein (Fig. 9 b).

\subsection{Effect of Panax ginseng on liver ultrastructure of LCT- intoxicated rats}

Electron microscopic examination of control rats liver sections showed normal ultrastructure. The hepatocyte cytoplasm includes various mitochondria that appear round in shape. The rough endoplasmic reticulum 


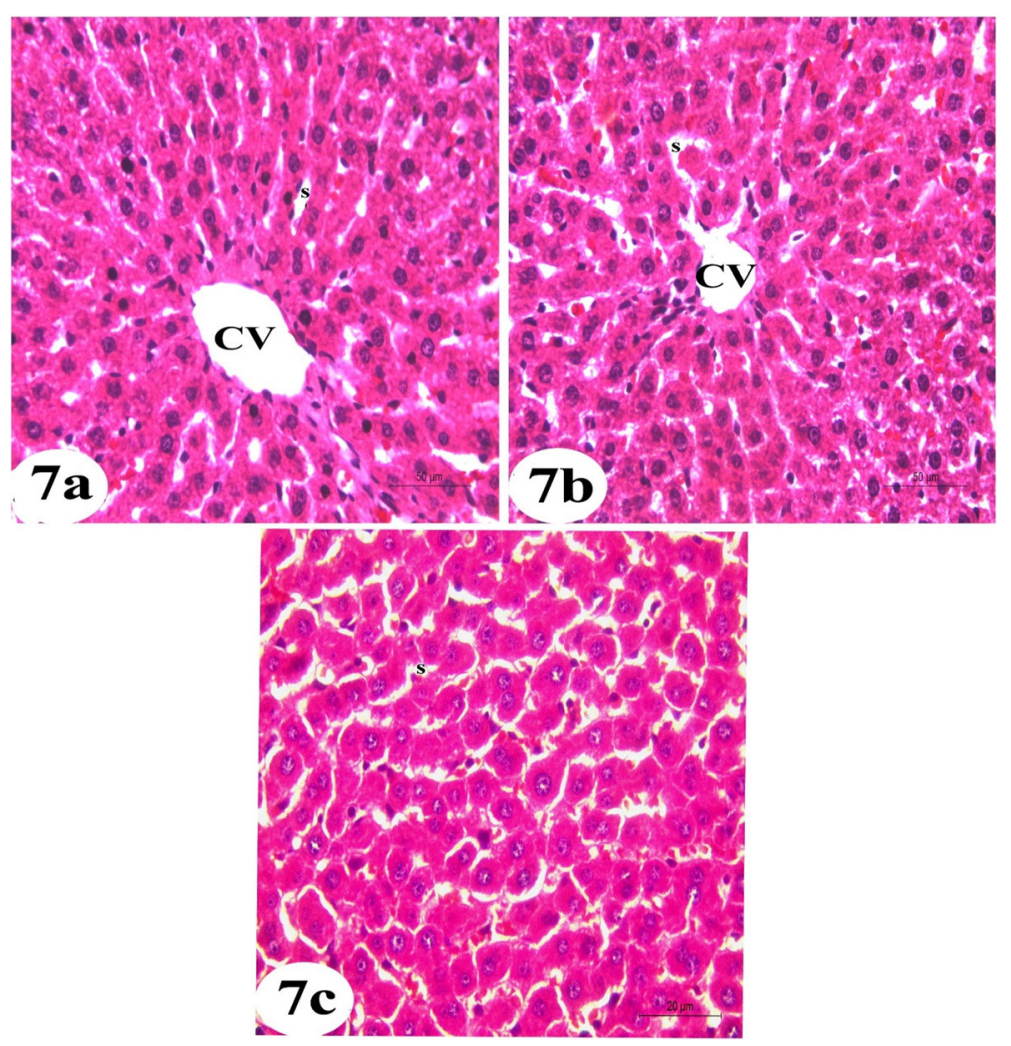

Fig. 7 Photomicrographs of sections of liver of $\mathbf{a}$ control rats and $\mathbf{b}$, c ginseng groups, treated with 100 and $200 \mathrm{mg} / \mathrm{kg}$ b. wt./day respectively, stained with H\&E: showing normal histological structure of liver; radially arranged polyhedral hepatocytes forming cords around the central vein (CV) and sinusoids (S) (scale bar $=50 \mu \mathrm{m}$ )

consists of closely pack parallel and flattened cisternae. Several electron-dense glycogen rosettes were obviously observed. The hepatocyte nucleus appears spherical with a distinct nuclear envelope and one or more prominent nucleoli. The nucleoplasm revealed a unrivaled distribution of a little quantities of heterochromatin peripherally and centrally large quantity of euchromatin. Normal bile canaliculi with normal structure of microvilli appeared. Also, Kupffer cell with normal nucleus was observed (Fig. 10 a, b).

LCT-intoxicated rats revealed marked ultrastructural changes. In hepatocytes, the mitochondria appeared vacuolated, cytoplasmic vacuolations, fat droplets, and collagen fibers were also observed (Fig. 11 a-c, e). Damaged bile canaliculi with destructed microvilli (Fig. $11 \mathrm{~d}$ ) and damaged Kupffer cell with shrinked nucleus (Fig. 11 a) were also seen.

On the other hand, treatment of LCT-intoxicated rats with $100 \mathrm{mg} \mathrm{G} / \mathrm{kg}$. b. wt./day resulted in relative improvement in the constituents except some cytoplasmic valuation and some fat droplets in hepatocyte (Fig. 12 ac). While treatment of LCT-intoxicated rats with 200 $\mathrm{mg} \mathrm{G} / \mathrm{kg} \mathrm{b}$. wt./day restore normal appearance of hepatocyte, Kupffer cell, and bile canaliculi (Fig. 13 a-c).

\section{Discussion}

LCT, pyrethroid insecticide type II, is extensively utilized in public health and agriculture controlling pests [38]. Its widespread use consequently leads to the exposure of its possible toxic effects either directly by exposure of field applicators, manufacturing workers, and the ecosystem or indirectly by consumption of vegetables, fruits [39], and meat or milk of animals that exposed to LCT [40, 41].

Liver is the principal site of pyrethroid metabolism where large quantities of their metabolites are accumulated [42]. LCT metabolism occur rapidly in liver by hydrolytic cleavage of ester and oxidative pathways via CYP450 enzymes leading to ROS [43] causing damage of various components of cell membranes [14] resulting in alterations the antioxidant status, ROS, the antioxidant enzymes, LPO [44], and apoptosis that represent major contributors in hepatic damage. Thus, our study estimates the potential ameliorative effect of $\mathrm{G}$ in rat model of LCT-induced hepatotoxicity.

In the current study, terminal body weight and relative weight of liver of LCT-intoxicated rats were reduced that run in a good agreement with previous studies [14, 45-48]. 


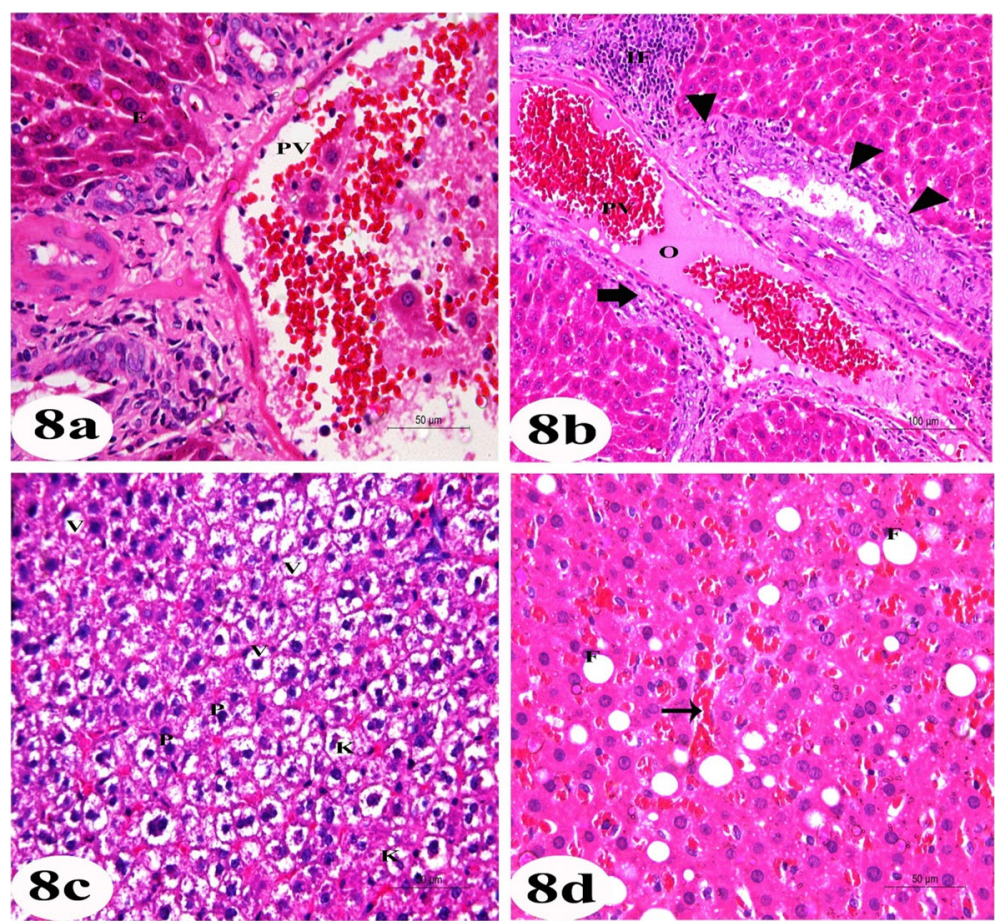

Fig. 8 Photomicrographs of sections of liver of LCT-treated rats for 60 days stained with H\&E. a, b Showing mononuclear leukocytic infiltration (IF), congested portal vein (PV) with thickened wall (thick arrow), edema (O), eosinophilic hepatocytes (E), and proliferation of bile duct, where some of them with hyperplastic wall (arrow head) (scale bar $=50$ and $100 \mu \mathrm{m}$ respectively). c, d Showing extensive vacuolar degeneration ( $\mathrm{V}$ ) of hepatocytes, dilated hyperemic sinusoids (thin arrow), and many hepatocytes with pyknotic (P) and karyolytic (K) nuclei, fatty changes (F) (scale bar $=50 \mu \mathrm{m})$

Elhalwagy et al. [1] demonstrated that decreasing body weight and organs relative weight is one of the chronic effects of pyrethroids toxicity. In LCT-intoxicated rats, the observed decrease may be directly linked to hypophagia or emaciation because of LCT's direct cytotoxicity [45].

Both in vivo and in vitro researches reported that $G$ decrease biological, physical, and chemical stress and maintain general vitality [49]. In our study, treatment of rats with LCT in concomitant with G 100 or $200 \mathrm{mg} / \mathrm{kg}$ b. wt./day increased terminal body weight, relative weight of liver, as compared to LCT-intoxicated ones matching with previous studies. Qadir et al. [50] demonstrated that $\mathrm{G}$ protects mice from body weight loss and improved kidney weight induced by gentamicin toxicity.

The current study indicated that LCT-intoxication caused extensive damage in the liver of rats that was confirmed by the histopathological and ultrastructural alterations and reflected by marked elevations of AST, ALT, and ALP activities, which are the circulating markers of hepatocytes injury.

Increased serum ALT and AST activities reflect LCTinduced hepatotoxicity, causing these enzymes to leak into blood [51, 52]. These observations matched with earlier finding of LCT toxicity in rats $[1,8,15,47,53$,
54]. ALT activity reflects general hepatic damage and AST activity indicates mitochondrial damage; elevated levels of ALP in blood are regarded as an indicator of hepatic necrosis and cholestasis $[55,56]$. The elevated levels of serum ALT and AST have been related to liver structural integrity damage $[57,58]$, as they are cytoplasmic enzymes and are released into blood after hepatic injury [59]. Releasing of metabolically toxic intermediates able to cause hepatocellular injury which happen during LCT metabolism in the liver, leading to these enzymes leakage to blood [60]. The increase or decrease of enzyme activity depends on the intensity of cellular damage. In the present study, the increased LPO products (MDA) level in liver of LCT-intoxicated rats and the elevation AST and ALT activities in serum proposed that LCT induced hepatocellular injury and this injury happened likely by ROS. That suggests that an elevation in the activity ALT in parallel with reduction in free radical scavenging enzymes activities $[1,14,53]$ could be representative of LCT-induced hepatic pathological alterations.

ALP is excreted through the liver by bile. Cholestasis, due to bile duct obstruction, cause enzymes to regurge that raise its blood level due to its back pressure that lead it to leach into blood. Biliary impairment could be 


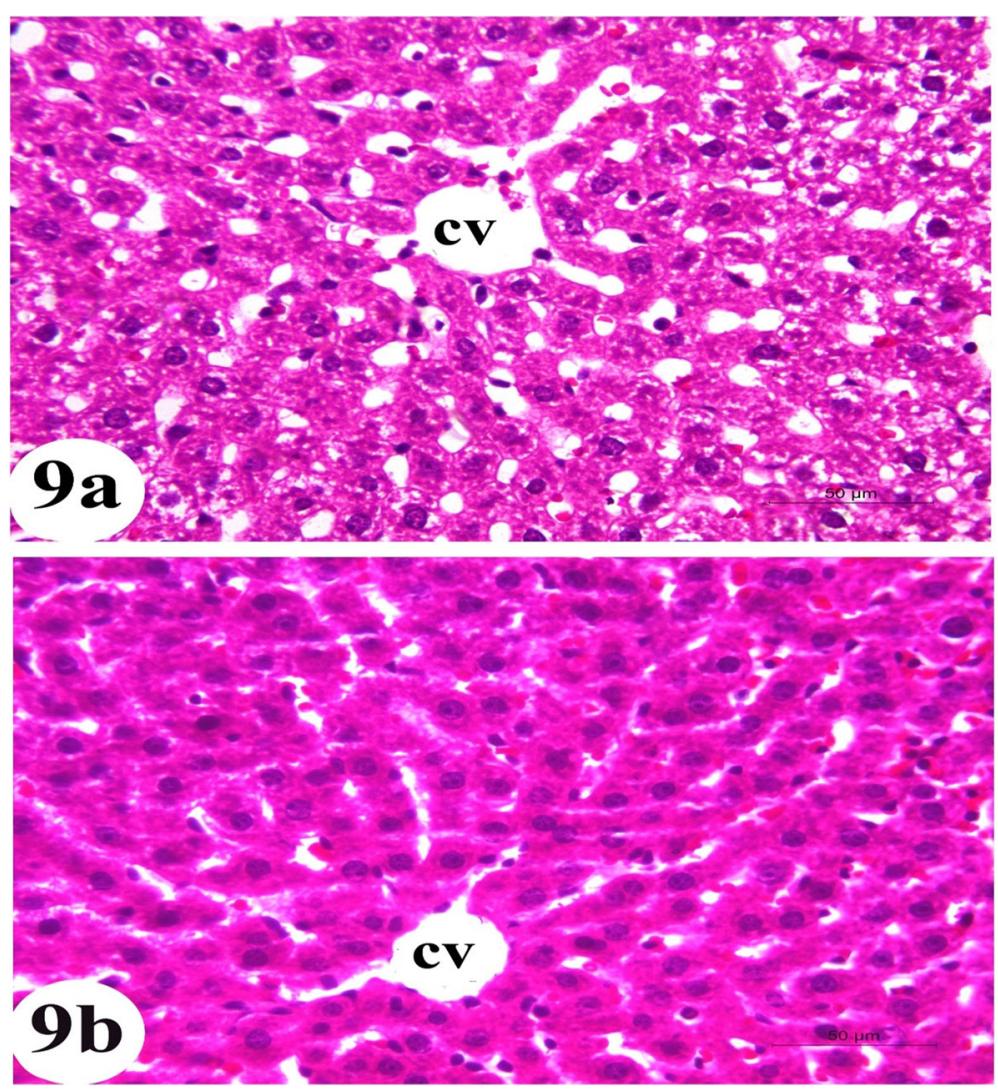

Fig. 9 Photomicrographs of sections of liver of treated rats stained with H\&E a with LCT plus ginseng $100 \mathrm{mg} / \mathrm{kg}$ b. wt./day showing relative recovery except vacuolar degeneration of hepatocytes and dilated sinusoids (scale bar $=50 \mu \mathrm{m}$ ). b With LCT plus ginseng $200 \mathrm{mg} / \mathrm{kg}$ b. wt./day group showing approximate regain of normal appearance of hepatocytes and central vein (CV) (scale bar $=50 \mu \mathrm{m})$

explained similarly. Elevated ALT, AST, and LDH activities concomitant with an increase in level of bilirubin in serum indicate cholestasis that lead to elevated serum ALP level [61]. Destruction of hepatic tissue (necrosis) also may have accounted for elevation in ALP level in serum. Because of pesticide toxicity, parenchymal cells of liver are deteriorated and necrosed, thus ALT, AST, and ALP release into the circulating blood stream, resulting in increased levels [62, 63]. Bhushan et al. [56] reported that an increase of serum ALP could be linked initially to some hepatic patho-physiological alterations as a result of pesticide toxicity, likely because of hepatocytes membrane permeability damage, so enzymes leak to blood stream.

In the present study, treatment of LCT-intoxicated rats with either 100 or $200 \mathrm{mg} \mathrm{G} / \mathrm{kg}$ b. wt./day produced a profound improvement of the altered ALT, AST, and ALP activities in serum. G reduced the elevated of AST, ALT, and ALP activities in serum of fipronil intoxicated rats and $100 \mathrm{mg} \mathrm{G} / \mathrm{kg} \mathrm{b}$. wt./day [64] or chlorpyrifos and profenofos and $200 \mathrm{mg} \mathrm{G} / \mathrm{kg} \mathrm{b}$. wt./day [65], conforming the protective effect of $\mathrm{G}$ against liver damage.
Oxidative stress has been described as losing balance between antioxidants and oxidants due to general elevation in ROS cellular levels [66]. It is known as a risk factors for the development of various diseases [67].

ROS are compounds that contain oxygen generated via general metabolic pathways, which are reported to cause oxidative damage to lipids, proteins, and nucleic acid [68].

Pesticides cause oxidative stress that leads to free radicals formation, changes in the levels of antioxidants, and LPO [69]. LPO is widely used as an oxidative stress marker. MDA is a main oxidation product of peroxidized polyunsaturated fatty acids and elevated MDA level is a LPO's accurate determinant [70]. In the current study, LCT produced a significant increase in the level of MDA in liver tissues. The increase in extent of LPO likely because of free radicals production as a result of LCT exposure. These observations are matched with earlier finding of LCT-hepatotoxicity $[1,8,14,53,54,71]$.

LPO results from lipid reaction with free radicals and this is regarded as a significant aspect of cellular damage caused by attacks of free radical [72]. This indicates that 

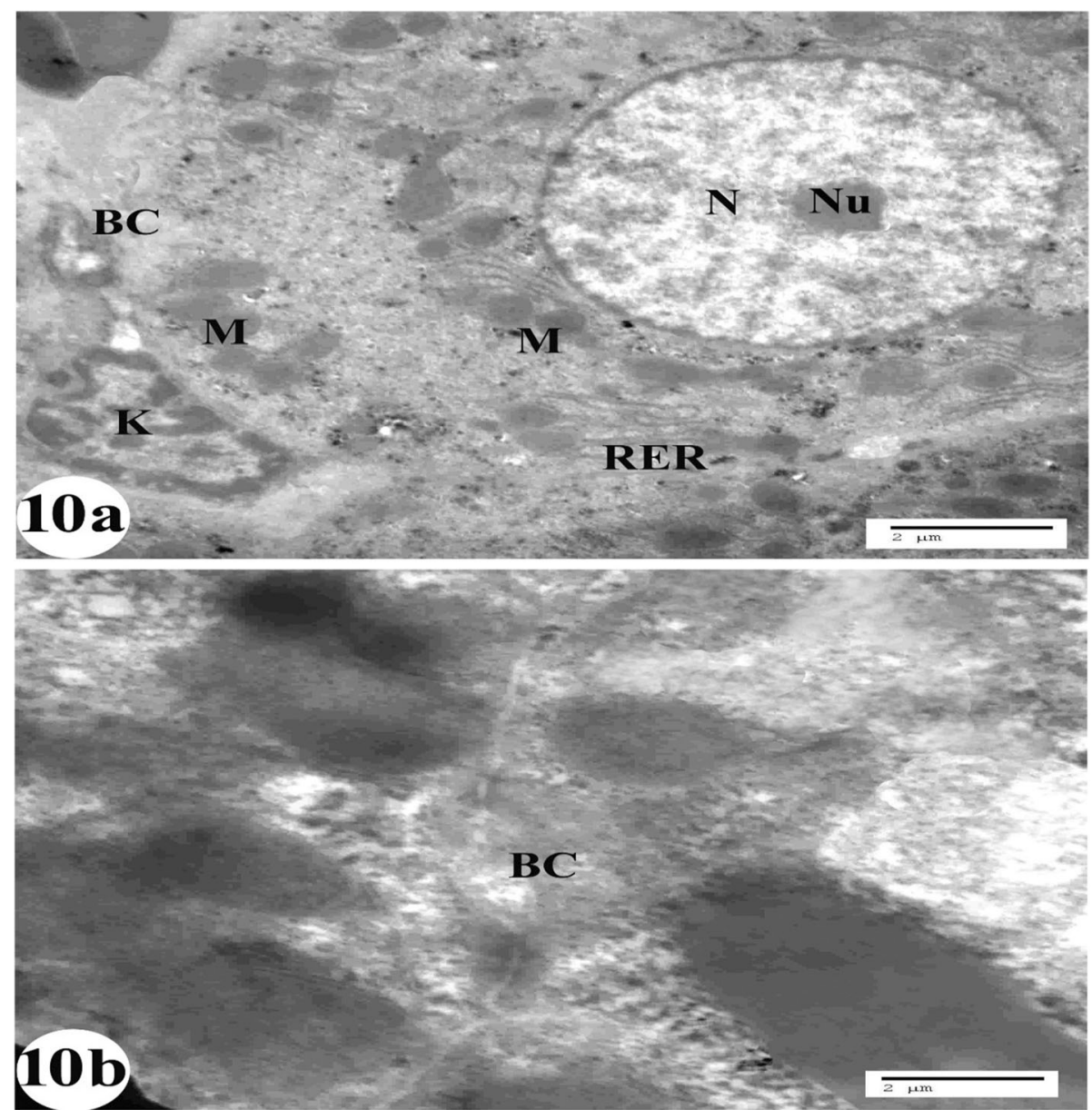

Fig. 10 Electron micrographs of a sections of liver of a control rats a showing hepatocytes contains numerous mitochondria (M), rough endoplasmic reticulum (RER) consists of closely pack parallel and flattened cisternae, spherical nucleus $(\mathrm{N})$ appears with a distinct nuclear envelope and prominent nucleoli (Nu), Kupffer cell (K) with normal nucleus and normal bile canaliculi (BC) (scale bar $=2 \mu \mathrm{m}$ ). b Showing high magnification of normal bile canaliculi (BC) with normal structure of microvilli (scale bar $=2 \mu \mathrm{m})$

elevated LPO could be among the molecular mechanisms implicated in the toxicity caused by LCT in rats.

Even so, in case of heavily established oxidative stress, the defense capacities against ROS becomes insufficient; in turn, ROS also affect the antioxidant defense mechanisms, decreases the intracellular thiol level, the antioxidant enzymes activities is altered, and MDA is increased [71]. Indirectly, these indicate an elevated generation of oxygen free radicals. Highly reactive oxygen metabolites, especially ${ }^{\circ} \mathrm{OH}$, produce MDA by acting on unsaturated fatty acids of phospholipid components of membranes [73].

CAT and SOD play a major role in quenching of ROS. SOD act as catalyst for breaking down of $\mathrm{O}_{2}{ }^{-}$to $\mathrm{H}_{2} \mathrm{O}_{2}$, while CAT act as catalyst for decomposition of $\mathrm{H}_{2} \mathrm{O}_{2}$ into $\mathrm{H}_{2} \mathrm{O}$ and $\mathrm{O}_{2}$ to inhibit oxidative stress and to maintain cell homeostasis. In the current study, CAT and SOD activities were significantly reduced in liver of LCT-treated rats that run in parallel with the results of
$[8,15,25,74,75]$. Both CAT and SOD act with each other for ROS elimination, and minor deviations in physiological levels could have a dramatic effect on cellular proteins, nucleic acid, and lipids resistance to oxidative stress [76]. In the LCT group, low CAT and SOD levels may be attributed to these enzymes consumption due to elevated oxidative stress in liver.

Thiols are a sulphydryl group containing organic compounds. Among all the body's antioxidants, thiols represent the main part of the total body antioxidants and they have an important role in defense against ROS. Thiols comprised of both extracellular and intracellular thiols either in the free form as reduced or oxidized glutathione, and protein-bound thiols [77]. In the current study, T. thiol is decreased in liver of LCTintoxicated rats matching those of previous study [71].

Antioxidants are the compounds which react with ROS for slowing their action and for neutralizing them, thus reducing oxidative stress and protecting us from 

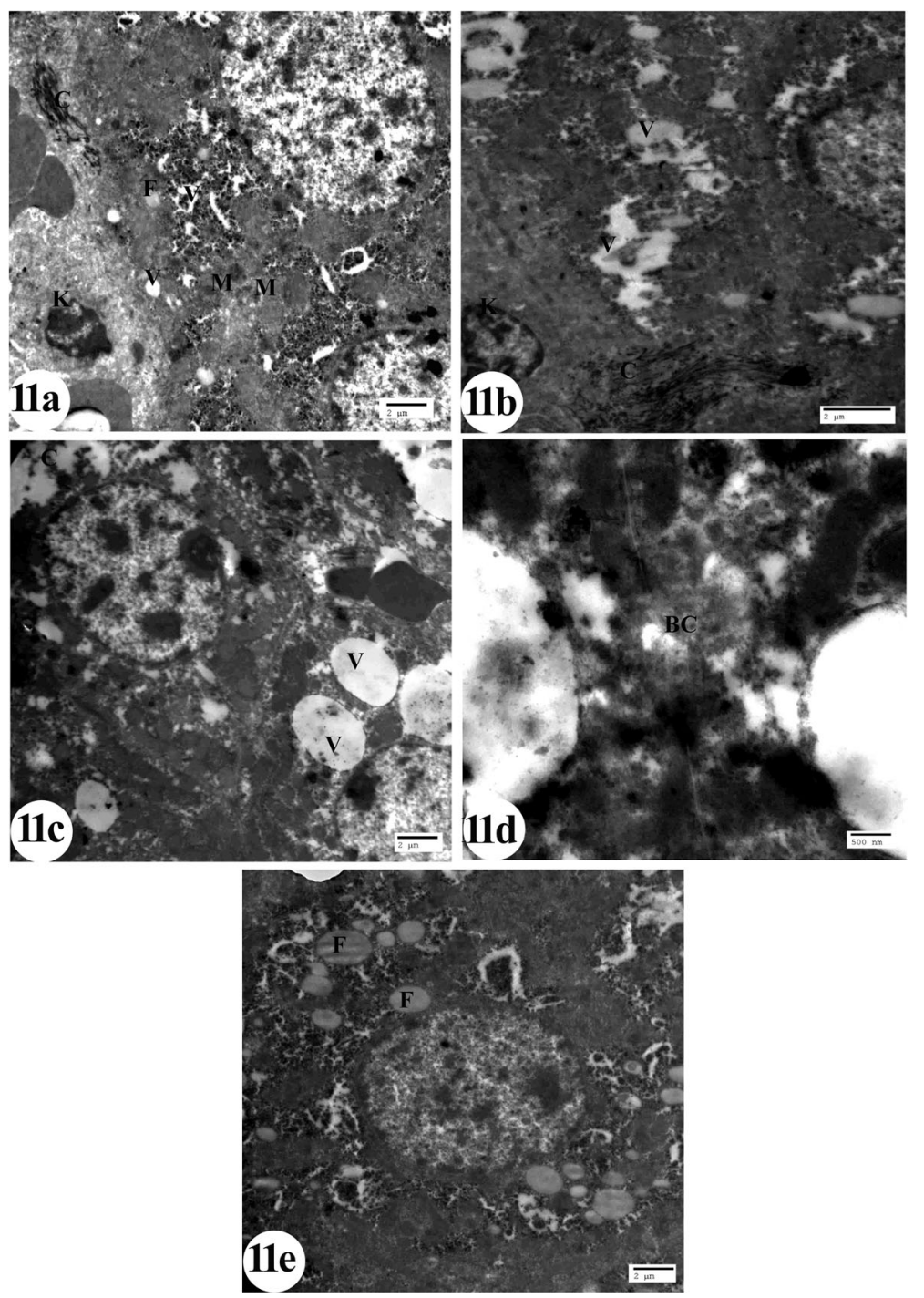

Fig. 11 Electron micrographs of a sections of liver of rats treated with $L C T$ a-c, e showing hepatocytes with cytoplasmic vacuolations ( $V$ ), vacuolated mitochondria (M), fat droplets (F), collagen fibers (C), and damaged Kuppfer cell (K) (scale bar $=2 \mu \mathrm{m})$. d Bile canaliculi with damaged microvilli (BC) (scale bar $=500 \mathrm{~nm})$

ailments [78]. Normally, our cells are able to inhibit ailments caused by free radicals by producing its endogenous antioxidants or via taking them from food [79]. Some synthetic antioxidants were used for preventing oxidative stress may cause side effects [16]. Thus, the regular consumption of natural antioxidant in diets is regarded very important to ban a broad spectrum of ailments, such as allergies, some types of cancer, hepatic and cardiovascular ailments, and inflammation that include free radical-mediated damage in pathologically generating processes [80].

The antioxidant properties of $\mathrm{G}$ are well documented. $\mathrm{G}$ exhibits antioxidant activity by improving the expressions of antioxidant enzyme genes that help to scavenge ROS. G intake stimulates both antioxidant enzyme activity and scavenging of free radicals [81]. G improved the antioxidant defense mechanism by increasing selfantioxidant enzyme activities (SOD, CAT, GPx, GR, GSH) and heme oxygenase- 1 in the aged-rat liver [19, $21]$ and inhibition of lipid peroxidation [23, 28]. However, its effect on inhibition of hepatotoxins-induced liver damages in rats cannot be neglected [22, 82].

In the present study, co-administration of $\mathrm{G}$ with LCT caused a significant decrease in the mean value of MDA and a significant increase in the mean values of antioxidant enzymes (SOD and CAT) activities and T. thiol in liver as compared with LCT-treated group. Similarly, AlHarbi et al. [64] demonstrated that G, due to its antioxidant properties, reduced MDA level, and elevated CAT and SOD activities in fipronil treated rats. Also, Diab 

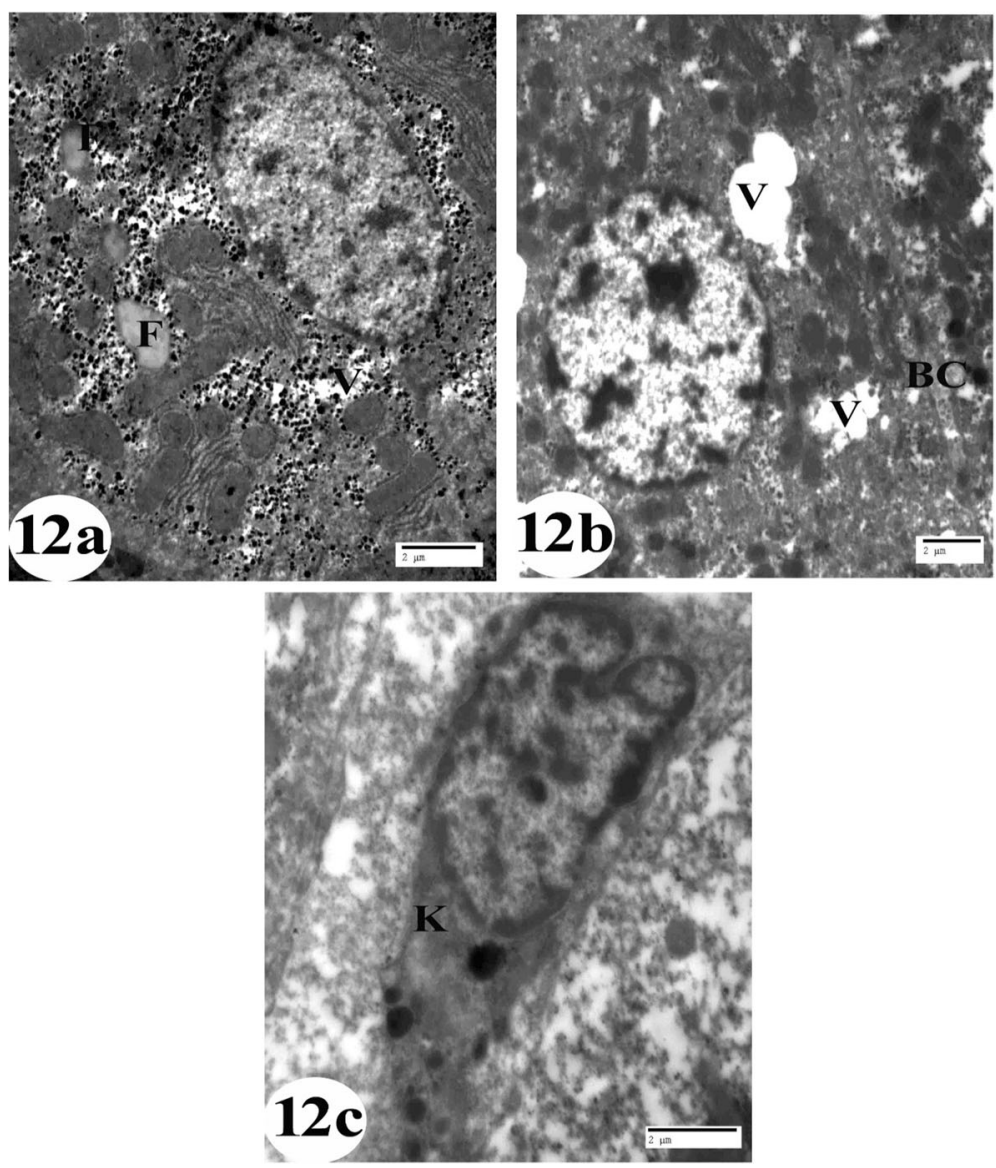

Fig. 12 Electron micrographs of a sections of liver of $L C T+100 \mathrm{mg}$ ginseng $/ \mathrm{kg}$ b. wt./day treated rats $\mathbf{a}$, $\mathbf{b}$ showing hepatocyte except some cytoplasmic vacuolations $(V)$, some fat droplets $(F)$, and normal bile canaliculi (BC) (scale bar $=2 \mu \mathrm{m})$. c Showing Kuppfer cell $(\mathrm{K})(\mathrm{scale}$ bar $=$ $2 \mu \mathrm{m})$

et al. [65] reported that $\mathrm{G}$ administration decreased MDA levels, and increased SOD, CAT activities in chlorpyrifos and profenofos-treated animals.

In conjunction with impaired antioxidant defense system, the present study exhibited significant elevation in mRNA and protein expression levels of hepatic p53 concomitant with decrease in mRNA and protein expression levels of Bcl2 in LCT-treated rats in comparison with control group. Apoptosis, the process of programmed cell death, is necessary for management of numbers of cells by elimination of damaged cells for better functioning of the body. But excessive tissue damage is caused by an uncontrolled and unconditioned apoptosis. Exposure of rats to LCT results in the generation of ROS, DNA fragmentation, and apoptosis [53, 66]. A possible mechanism of LCT-caused apoptosis was demonstrated to be related with activation of a transcription factor, nuclear factor-kappa B (NF-kB) which is a critical activator of genes involved in immunity, inflammation, and apoptosis [66]. However our study did not estimate NF-kB; Martínez et al. [66] reported an elevation of mRNA expression level of NF- $\mathrm{kB}$ and interleukin (IL-1 $\beta$ ) in hepatic tissues secondary to LCT-induced oxidative stress. Activation of NF- $\mathrm{kB}$ causes reduction in proliferation of cells and elevation in apoptosis by ROS-caused DNA damage and p53 activation. Activated p53 due to LCT oral exposure also activates the intrinsic mitochondrial apoptotic pathways responding to DNA damage by stimulating the expression of pro-apoptotic proteins (Bax, Casp-3), downregulates Bcl-2 expression, and shifts the balance toward pro-apoptotic effects [66]. Cotreatments with G significantly decrease mRNA and protein expression of p53 and increase mRNA and protein expression of Bcl-2 in hepatic tissue in comparison with LCT group. Thus, it is logical to believe that an enhanced apoptotic rate in co-treated groups can be ascribed to antioxidant properties of $\mathrm{G}$ and the subsequent ROS scavenging, suppression of NF- $\mathrm{kB}$ activation, and cytokines release. $\mathrm{G}$ decreased the gene expression of the pro-apoptotic proteins p53 and caspase-3, while elevated expression of the anti-apoptotic $\mathrm{Bcl} 2$ in neuroblastoma cells suggesting the protective effects of $G$ 


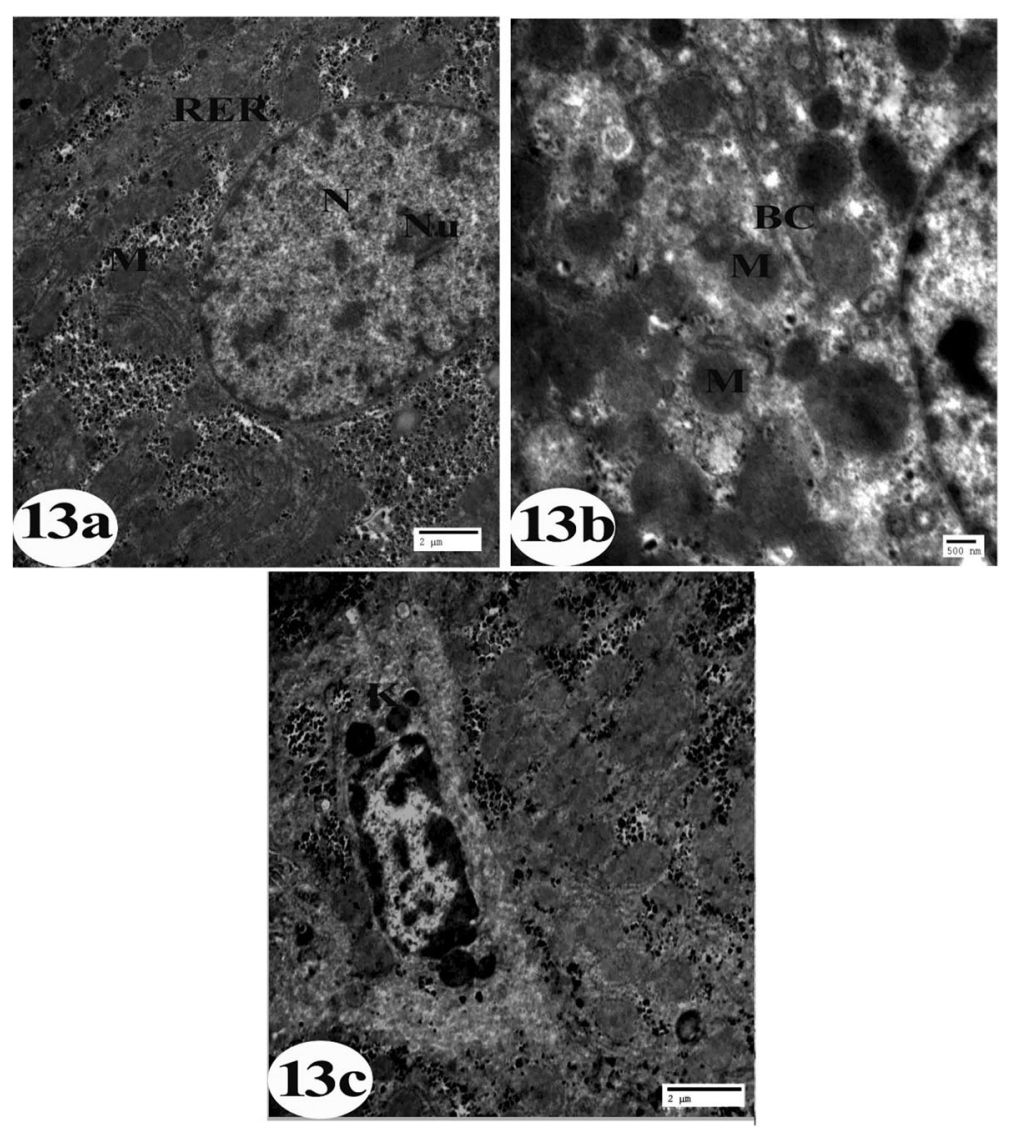

Fig. 13 Electron micrographs of a sections of liver of $L C T+200 \mathrm{mg}$ ginseng/kg b. wt./day treated rats $\mathbf{a}$, $\mathbf{b}$ showing normal hepatocyte with spherical nucleus $(\mathrm{N})$ appears with a distinct nuclear envelope and prominent nucleoli (Nu), numerous mitochondria (M), rough endoplasmic reticulum (RER), and normal bile canaliculi (BC) (scale bar $=2 \mu \mathrm{m}$ and $500 \mathrm{~nm}$ respectively). c Showing normal ultrastructure of Kuppfer cell (K) (scale bar $=2 \mu \mathrm{m}$ )

against the cell death in oxidative stressed brain cells [83]. Also, G suppresses TNF- $\alpha /$ IFN-c-induced thymusand activation-regulated chemokine (TARC) expression through NF-kB-dependent signaling in $\mathrm{HaCaT}$ cells. G improved 2,4-dinitrochlorobenzene (DNCB)-induced dermatitis severity, serum levels of IgE and TARC, and mRNA express ion of TARC, TNF- $\alpha$, IFN-c, IL-4, IL-5, and IL-13 in mice. G inhibited TNF- $\alpha$ /IFN-c-induced NF- $\kappa B$ activation [84].

Another molecular mechanism study found that $G$ suppresses nuclear factor-kappa B (NF-kB) $[85,86]$.

The present histopathological observations of liver sections of LCT-intoxicated rats showed mononuclear leukocytic infiltration, portal vein congestion with thickening in wall, and bile duct proliferation was also observed. In addition to hyperemic sinusoids, fatty changes, and edema. Degenerative changes were seen in the hepatocytes in the form of vacuolar degeneration, hypereosinophilic cytoplasm, pyknosis, and karyolysis, in agreement with previous studies [15, 87, 88]. Also, Abdul Basir et al. [89] reported that LCT-intoxicated rabbits exhibited hemorrhages in sinusoidal spaces hyperplasia of bile duct, karyolysis, and vacuolation. LCT-intoxicated mice also showed hepatocyte degeneration, vascular degeneration, mononuclear leukocytic infiltration, and portal vein appeared dilated and congested [90, 91].

In addition to similar histopathological observations, it has been reported by Mossa et al. [92] and Abdulhamid et al. [93] on the effect of cypermitherin (CYP), type II pyrithroids, on liver tissue. These histopathological changes in the hepatocytes due to CYP's inhibitory action on total adenine triphosphate (ATP) activity in the liver, that can disturb active transport of $\mathrm{Ca}^{2+}, \mathrm{K}^{+}$, and $\mathrm{Na}^{+}$ions, inducing hepatocytes damage [94].

Matching with histopathological findings, our ultrastructural study showed that LCT-intoxicated rats exhibited damaged bile canaliculi with destructed microvilli, Kupffer cell showed shrinked nucleus, hepatocytes with vacuolated mitochondria, cytoplasmic vacuolations, fat droplets, and collagen fibers in parallel line with similar 
previous studies. Marked ultrastructural alterations were exhibited in previous studies of CYP intoxicated rats. In hepatocytes, mitochondria looked swollen, vacuolated with destructed cristae, cytoplasmic vacuolations, complete lysis of nucleus and dilated bile duct with destruction in microvilli, fat droplets, and cytoplasmic vacuoles were also observed. Moreover, Kupffer cell appeared with elongated nucleus, endocytic vesicles, and noticeable elevation in number of lysosomes $[93,95,96]$.

Concerning the hepatocytes, fatty changes in the form of fat droplets in the cytoplasm can be rationalized by the high levels of LPO that resulted from LCT-induced oxidative damage, and its effect on membrane phospholipids.

After several types of hepatocellular damage, healing normally occur by regeneration of parenchymal cells and substitution of stromal elements coordinately that preserves accurately the lobular architecture of hepatic tissue. While, in some cases for unknown causes, abnormal quantities of collagen accumulate impairing the normal relationships between the parenchymal cells and its blood supply. That is known as liver fibrosis or cirrhosis, which can impair hepatic function or even death [97] that matching with the current ultrastructural observation of collagen accumulation in hepatic tissue of LCT-intoxicated rats.

In the current study, treatment of LCT-intoxicated rats with G $100 \mathrm{mg} / \mathrm{kg}$ b.wt./day and $200 \mathrm{mg} / \mathrm{kg}$ b. wt./ day plus LCT protected liver of LCT hepatic toxicity and maintain approximately the normal histological structure matching with similar previous studies. El-Bialy et al. [9] demonstrated that G $200 \mathrm{mg} / \mathrm{kg}$. b. wt./day ameliorates LCT and acetamiprid pesticides mixture for hepatotoxicity in rats and restore normal hepatic architecture.

\section{Conclusion}

The current study reported that $G$ has shown therapeutic efficacy against LCT-induced histopathological and ultrastructural hepatic damage in rats. Moreover, the mechanisms sharing in its therapeutic efficacy involved free radicals scavenging, enhancing the antioxidants status, and anti-apoptotic properties were shown. Further researches are needed to illustrate the molecular mechanism of G against LCT-induced hepatotoxicity.

\section{Abbreviations}

LCT: Lambda-cyhalotherin; LPO: Lipid peroxidation; MDA: Malonaldehyde; ROS: Reactive oxygen species; CAT: Catalase; SOD: Superoxide dismutase; T. thiol: Total thiol; ALT: Alanine aminotransferase; AST: Aspartate aminotransferase; ALP: Alkaline phosphatase; qPCR: Quantitative polymerase chain reaction; G: Panax ginseng

\section{Acknowledgements}

Not applicable.

\section{Authors' contributions}

All authors have contributed significantly, Prof. Dr. MA, Dr. Prof. HMA, and Prof. Dr. SA have contributed in suggesting design of the work, preparation and analysis of the results, interpretation of data and discussion. In addition Mr. KZ has performed the practical part. All authors are in agreement with the contents of the manuscript. All authors read and approved the final manuscript.

\section{Funding}

None.

\section{Availability of data and materials}

All data generated or analyzed during this study are included in this published article.

\section{Ethics approval and consent to participate}

In this study, animal care was carried out following the European

Community Directive (86/609/EEC) and national rules, this is in accordance with the NIH Guidelines for care and use of Laboratory Animals, $8^{\text {th }}$ editions. This was administrated by the committee of the Zoology Department, BeniSeuf University, Egypt.

\section{Consent for publication}

Not applicable.

\section{Competing interests}

The authors declare that they have no competing interests.

Received: 29 June 2020 Accepted: 4 September 2020

Published online: 03 December 2020

\section{References}

1. Elhalwagy MEA, Darwish NS, Zaher EM (2008) Prophylactic effect of green tea polyphenol against liver and kidney injury induced by fenitrothion insecticides. Pesti Bio Physio 91:81-89

2. Erstfeld KM (1999) Environmental fate of synthetic pyrethroids during spary drift and field runoff treatments in aquatic microcosms. Chemosphere 39(10):1737-1769

3. Casida JE, Quistad GB (1998) Golden age of insecticide research: past, present, or future? Annu Rev Entomol 43:1-16

4. Casida JE (1980) Pyrethrum flowers and pyrethroid insecticides. Environ. Health Perspect 34:189-202

5. Saka WA, Akhigbe RE, Azeez OM, Babatunde TR (2011) Effect of pyrethroid exposure on haematological and haemostatic profiles in rats. Pakistan J Biol Sci 14:1024-1027

6. Abdel Aziz KB, Abdel Rahem HM (2010) Lambda, the pyrethroid insecticide as a mutagenic agent in both somatic and germ cells. J Am Sci 6(12):317326

7. Mulambalah CS, Siamba DN, Ngeiywa MM, Vulule JM (2010) Evaluation of lambda-cyhalothrin persistence on different indoor Surfaces in a malaria epidemic-prone area in Kenya. J Boil Sci 35(2):124-135.

8. Moustafa GG, Hussein MMA (2016) Lambda cyhalothrin toxicity induces alterations in lipogenic genes and inflammatory factors in rat liver. Jpn J Vet Res 64(1):25-38

9. El-Bialy BES, Abd Eldaim MA, Hassan A, Abdel-Daim MM (2019) Ginseng aqueous extract ameliorates lambda-cyhalothrinacetamiprid insecticide mixture for hepatorenal toxicity in rats: Role of oxidative stress-mediated proinflammatory and proapoptotic protein expressions. Environ Toxicol. 35(2):124-135

10. Kale M, Rathore N, John S, Bhatnagar D (1999) Lipid peroxidative damage on pyrethroid exposure and alterations in antioxidant status in rat erythrocyte: a possible involvement of reactive oxygen species. Toxicol Lett 105:197-205

11. Romero A, Ramos E, Castellano V, Martínez MA, Ares I, Martínez M, Martínez Larranaga MR, Anadón A (2012) Cytotoxicity induced by deltamethrin and its metabolites in SH-SY5Y cells can be differentially prevented by selected antioxidants. Toxicol Invitro 26:823-830

12. Borza LRA (2014) Review on the cause-effect relationship between oxidative stress and toxic proteins in the pathogenesis of neurodegenerative diseases. Rev. Med. Chir. Soc Med Nat lasi 118:19-27

13. El-Demerdash FM (2007) Lambda-cyhalothrin-induced changes in oxidative stress biomarkers in rabbit erythrocytes and alleviation Effect of some antioxidants. Toxicol. In Vitro 21:392-397

14. Fetoui H, Garoui EM, Makniayadi F, Zeghal N (2008) Oxidative stress induced by lamda-cyhalothrin (LTC) in rat erythrocytes and brain: attenuation by vitamin C. Environ. Toxicol Pharmacol 26:225-231 
15. Fetoui H, Garoui EM, Zeghal N (2009) Lambda cyhalothrin induced biochemical and histopathological changes in the liver of rats: ameliorative effect of ascorbic acid. Exp Toxicol Pathol 61:189-196

16. Cornwell DG, Jones KH, Jiang Z, Lantry LE, Southwell-Keely P, Kohar I, Thornton DE (1998) Cytotoxicity of tocopherols and their quinones in drugsensitive and multidrug-resistant leukemia cells. Lipids 33(3):295-301

17. Hong SH, Suk KT, Choi SH, Lee JW, Sung HT, Kim CH (2013) Antioxidant and natural killer cell activity of Korean red ginseng (Panax ginseng) and urushiol (Rhus vernicifera Stokes) on non-alcoholic fatty liver disease of rat. Food Chem Toxicol 55:586-591

18. Kim MK, Lee JW, Lee KY, Yang D (2005) Microbial conversion of major ginsenoside Rb1 to pharmaceutically active minor ginsenoside Rd. J Microbiol 43(5):456-462

19. Ramesh T, Kim SW, Sung JH (2012) Effect of fermented Panax ginseng extract (GINST) on oxidative stress and antioxidant activities in major organs of aged rats. Exp Gerontol 47(1):77-84

20. Abdel-Wahhab MA, Gamil K, El-Kady AA, El-Nekeety AA, Naquib KM (2011) Therapeutic effects of Korean red ginseng extract in Egyptian patients with chronic liver diseases. J Ginseng Res 35(1):69-79

21. Kim YS, Kim YH, Noh JR, Cho ES, Park JH, Son HY (2011) Protective effect of korean red ginseng against aflatoxin B1-induced hepatotoxicity in rat. J Ginseng Res 35(2):243-249

22. Shukla R, Kumar M (2009) Role of Panax ginseng as an antioxidant after cadmium-induced hepatic injuries. Food Chem Toxicol 47(4):769-773

23. Yousef IM, Hussien HM (2015) Cisplatin-induced renal toxicity via tumor necrosis factor-a, interleukin 6, tumor suppressor P53, DNA damage, xanthine oxidase, histological changes, oxidative stress and nitric oxide in rats: Protective effect of ginseng. Food Chem Toxicol 78:17-25

24. Mohi-Eldin MM, Mostafa AM, Abd- El kader AA (2014) Experimental studies on the effect of (Lambda-Cyhalothrin) insecticide on lungs and the ameliorating effect of plant extracts (Ginseng Panax Ginseng) and garlic (Allium sativum L.) On asthma development in albino rats. BMC Res Notes 7 : 243

25. Ben-Abdallah F, Fetoui H, Zribi N, Fakhfakh F, Keskes L (2011) Quercetin attenuates lambda cyhalothrininduced reproductive toxicity in male rats. Environ Toxicol 28(12):673-680

26. Schumann G, Klauke R (2003) New IFCC reference procedures for the determination of catalytic activity concentrations of five enzymes in serum: preliminary upper reference limits obtained in hospitalized subjects. Clin. Chim. Acta 327(1-2):69-79

27. Wenger C, Kaplan A, Rubaltelli FF, Hammerman C. (1984) Alkaline phosphatase. Clin. Chem. The C.V. Mosby Co., St. Louis. Toronto. Princeton. 1094-1098

28. Rosalki SB, Foo AY, Burlina A, Prellwitz W, Stieber P, Neumeier D, Klein G, Poppe WA, Bodenmüller H (1993) Multicenter evaluation of Iso-ALP test kit for measurement of bone alkaline phosphatase activity in serum and plasma. Clin. Chem. 39(4, 1):648-652

29. Preuss HG, Jarrel ST, Scheckenobach R, Lieberman S, Anderson RA (1998) Comparative effects of chromium vanadium and Gymnemasylvestre on sugarinduced blood pressure elevations in SHR. J Am College Nutr 17(2):116 123

30. Koster JF, Biermond P, Swaak AJG (1986) Intracellular and extracellular sulphhydryl levels in rheumatoid arthritis. Annals of the Rheumatic Diseases 45:44-46

31. Cohen C, Dembiec D, Marcus J (1970) Measurement of catalase activity in tissue extracts. J Analytical Biochem 34:30-38

32. Marklund S, Marklund G (1974) Involvement of superoxide anion radical in the autooxidation of pyrogallol and convenient assay for superoxide dismutase. Eur J Biochem 47:469-474

33. Mahmoud AM (2014) Hesperidin protects against cyclophosphamideinduced hepatotoxicity by upregulation of PPARy and abrogation of oxidative stress and inflammation. Can J Physiol Pharm 92:717-724

34. Livak KJ, Schmittgen TD (2011) Analysis of relative gene expression data using real-time quantitative PCR and the 2(-Delta Delta $C(T)$ ). Method 25: 402-408

35. Mahmoud AM, Germous MO, Alotaibi MF, Hussein O (2017) Possible involvement of Nrf2 and PPAR gamma upregulation in the protective effect of umbelliferone against cyclophosphamideinduced hepatotoxicity. Biomed Pharmacother:7-306

36. Bancroft JD, Gamble M (2002) Theory and practice of histological techniques, 5th edn. Churchill Livingstone, London, pp 109-136
37. Bozzola JJ, Russell LD (1999) Electron microscopy: principles and techniques for Biologists. Jones and Bartlett Publishes, Sudbury, MA, USA

38. Amweg E, Weston D (2005) Use and toxicity of pyrethroid pesticides in the Central Valley, California, USA. Environ Toxicol Chem 24(5):1300-1301

39. Turgut C, Ornek H, Cutright TJ (2011) Determination of pesticide residues in Turkey's table grapes: the effect of integrated pest management, organic farming, and conventional farming. Environ Monit Assess 173:315-323

40. Bissacot DZ, Vassilieff I (1997) Pyrethroid residues in milk and blood of dairy cows following single topical applications. Vet Hum Toxicol 39:6-8

41. Muhammad F, Akhtar M, Rahman ZU, Farooq HU, Khaliq T, Anwar MI (2010) Multi-residue determination of pesticides in the meat of Cattle in Faisalabad- Pakistan. Egypt. Acad J Biol Sci 2(2):19-28

42. Giray B, Gurbay A, Hincal F (2001) Cypermethrin-induced oxidative stress in rat brain and liver is prevented by vitamin $\mathrm{E}$ or allopurinol. Toxicol Lett 118: 139-146

43. Sankar P, Telang AG, Manimaran A (2012) Protective effect of curcumin on cypermethrin-induced oxidative stress in Wistar rats. Exp Toxicol Pathol 64: 487-493

44. Etemadi-Aleagha A, Akhgari M, Abdollahi M (2002) A brief review on oxidative stress and cardiac diseases. Mid East Pharmac 10:8-9

45. Fetoui H, Zribi N, Fakhfakh F, Keskes L (2011) Quercetin attenuates Lambda cyhalothrin induced reproductive toxicity in male rats. Environ Toxicol 28(12):673-680

46. Yousef MI (2010) Vitamin E modulates reproductive toxicity of pyrethroid lambda-cyhalothrin in male rabbits. Food Chem Toxicol 48:1152-1159

47. Ghosh R, Das T, Paramanik A, Maiti-Choudhury S (2016) Lambda cyhalothrin elicited dose response toxicity on haematological, hepatic, gonadal and lipid metabolic biomarkers in rat and possible modulatory role of taurine. Toxicol Forensic Med Open J 1(2):42-51

48. Al-Amoudi WM (2018) Toxic effects of Lambda-cyhalothrin, on the rat thyroid: Involvement of oxidative stress and ameliorative effect of ginger extract. Toxicol Rep 5:728-736

49. Fan JS, Liu DN, Huang G, Xu ZZ, Jia Y, Zhang HG (2012) Panax notoginseng saponins attenuate atherosclerosis via reciprocal regulation of lipid metabolism and inflammation by inducing liver $\mathrm{x}$ receptor alpha expression. J Ethnopharmacol 142:732-738

50. Qadir MI, Tahir M, Lone KP, Munir B, Sami W (2011) Protective role of ginseng against gentamicin induced changes in kidney of albino mice. J Ayub Med Coll Abbottabad (JAMC) 23(4):53-57

51. El-Magd SAA, Sabik LME, Shoukry A (2011) Pyrethroid toxic effects on some hormonal profile and biochemical markers among workers in pyrethroid insecticide company. Life Sci J 8:311-322

52. GK B, IPS S, NK S, SK P, G S, JS B (2014) Ameliorative role of melatonin against cypermethrin induced hepatotoxicity and impaired antioxidant defense system in Wistar rats. IOSR J Environ Sci Toxicol Food Technol 8(1):39-48

53. Madkour NK (2012) Protective effect of curcumin on oxidative stress and DNA fragmentation against lambda cyhalothrin-induced liver damage in rats. J Appl Pharm Sci 2(12):76-81

54. Abdel- Mobdy YE, Abdel-Rahim EA (2015) Toxicological influences of lambda cyhalothrin and evaluation of the toxicity ameliorative effect of pomegranate in albino rats. Glob Vet 14(6):913-921

55. Padma W, Baskaran R, Roopesh RS, Poornima P (2012) Quercetin attenuates lindane induced oxidative stress in Wistar rats. Mol Biol Rep 39:6895-6905

56. Bhushan B, Pande S, Saxena N, Saxena PN (2013) Serum biochemical responses under stress of cypermethrin in albino rat. Environ. Exp Biol 11:81-89

57. Yanpallewar SU, Sen S, Tapas S, Kumar M, Raju SS, Acharya SB (2003) Effect of Azadirachta indica on paracetamol induced hepatic damage in albino rats. Phytomedicine 10:391-396

58. Yousef Ml, El-Demerdash FM, Kamil Kl, Al-Salhen KS (2003) Changes in some hematological and biochemical indices of rabbits induced by isoflavonen and cypermethrin. Toxicology 189:223-234

59. Shim JY, Kim MH, Kim HD, Ahn JY, Yun YS, Song JY (2010) Protective action of the immunomodulator ginsan against carbon tetrachlorine-induced liver injury via control of oxidative stress and the inflammatory response. Toxicol Appl Pharmacol 242:318-325

60. Bhushan B, Saxena N, Saxena PN (2010) Beta-cyfluthrin induced histochemical alteration in the liver of the albino rat. Scand J Lab Anim Sci 37:61-66

61. Pande S (2001) Effect of synthetic pyrethroids on certain haematobiochemical parameters of Rattus norvegicus. Ph.D. Thesis, Dr. In: B. R. Ambedkar University, Agra 
62. Ahmad L, Khan A, Khan MZ (2011) Cypermethrin induced biochemical and hepato-renal pathological changes in rabbits. Int J Agr Biol 13:865-872

63. Bhushan B, Saxena PN, Saxena N (2013) Biochemical and histological changes in rat liver caused by cypermethrin and beta-cyfluthrin. Arh Hig Rada Toksikol 64:57-67

64. Al-Harbi MS (2016) Fipronil induced hepatotoxicity, genotoxicity, oxidative stress and the possible ameliorative effect of ginseng. Br. J Pharm Res 14(5): $1-14$

65. Diab AA, Abd El-Aziz EA, Hendawy AA, Hamza RZ (2012) Possible ameliorative role of propolis and Ginseng against hepatotoxicity of chlorpyrifos and profenofos in male rats. J Am Sci 8(8):645-664

66. Martínez M, Ares I, Rodríguez J, Martínez M, Roura-Martínez D, Castellano V, Lopez-Torres B, Martínez-Larrañaga M, Anadón A (2018) Pyrethroid insecticide lambda-cyhalothrin induces hepatic cytochrome P450 enzymes, oxidative stress and apoptosis in rats. Sci. Total Environ 631-632):1371-1382

67. Dhalla NS, Temsah RM, Netticadan T (2000) Role of oxidative stress in cardiovascular diseases. J Hypertens 18(6):655-673

68. Bertram C, Hass R (2008) Cellular responses to reactive oxygen speciesinduced DNA damage and aging. Biol Chem 389(3):211-220

69. Ender $Y$, Onder C (2006) Effects of dichlorvos on lipid peroxidation in mice on subacute and subchronic periods. Pest Biochem Physiol 86:106-109

70. Draper HH, Hadley M (1990) Malondialdehyde determination as index of lipid peroxidation. Methods Enzymol 186:421-431

71. Aouey B, Derbali M, Chtourou Y, Bouchard M, Khabir A, Fetoui H (2017) Pyrethroid insecticide lambda-cyhalothrin and its metabolites induce liver injury through the activation of oxidative stress and pro-inflammatory gene expression in rats following acute and subchronic exposure. Environ Sci Pollut Res 24:5841-5856

72. Hoek JB, Pastorino JG (2002) Ethanol, oxidative stress and cytokine-induced liver damage. Alcohol 27(1):63-68

73. Mossa AH, Nawwar GA (2011) Free radical scavenging and antiacetylcholinesterase activities of Origanum majorana L. essential oil. Human Exp Toxicol 30:1501-1513

74. Abouzaid OAR, Abd El-Mageid AD, Alsadek EA (2015) Protective and treatment effect of garlic extract on biochemical changes induced by pesticides in rats. Benha Vet Med J 29(1):205-213

75. Metwally HG, Abd-Ellah HF, Shaheen NEM, Afifi MSH, Al-Zail NI (2017) Role of Mesenchymal stem cells in the treatment of testicular toxicity induced by Lambda-Cyhalothrin in Rats. Wulfenia J 24(10):108-138

76. Mates J, Sánchez-Jiménez F (1999) Antioxidant enzymes and their implications in pathophysiologic processes. Frontiers in bioscience: Journal Virtual Library (4.D):339-345

77. Prakash M, Shetty MS, Tilak P, Anwar N (2009) Total Thiols: biomedical importance and their alteration in various disorders. Online J Health Allied Scs 8(2.2):1-9

78. Majeed M, Nagabhushanam K, Choudhury AK (2016) Antioxidants: Balancing the Good, the Bad and the Ugly. Nutr Food Technol 2(2):1-4

79. Bouayed J, Bohn T (2010) Exogenous antioxidants-Double-edged swords in cellular redox state: Health beneficial effects at physiologic doses versus deleterious effects at high doses. Oxid Med Cell Longev 3(4):228-237

80. Cook NC, Samman S (1996) Flavonoids- chemistry, metabolism, cardioprotective effects, and dietary sources. Nut Biochem 7:66-76

81. Jung $\mathrm{CH}$, Seog HM, Choi IW, Choi HD, Cho HY (2005) Effects of wild ginseng (Panax ginseng C.A. Meyer) leaves on lipid peroxidation levels and antioxidant enzyme activities in streptozotocin diabetic rats. J Ethnopharmacol 98:245-250

82. Chang HF, Lin YH, Chu CC, Wu SJ, Tsai YH, Chao JCJ (2007) Protective effects of Ginkgo biloba, Panax ginseng, and Schizandra chinensis extract on liver injury in rats. Am J Chin Med 35(6):995-1009

83. Nguyen CT, Luong TT, Kim GL, Pyo S, Red RDKK (2015) Ginsenginhibits apoptosis in neuroblastoma cells via estrogen receptor b-mediated phosphatidylinositol-3 kinase/Akt signaling. J Ginseng Res 39(1):69-75

84. Choi JH, Jin SW, Park BH, Kim HG, Khanal T, Han HJ, Hwang YP, Choi-c JM, Chung YC, Hwang SK, Jeong TC, Jeong HG (2013) Cultivated ginseng inhibits 2, 4- dinitrochlorobenzene-induced atopic dermatitis-like skin lesions in NC/Nga mice and TNF- $a$ /IFN-c-induced TARC activation in HaCaT cells. Food Chem Toxicol 56:195-203

85. Kang KS, Yamabe N, Kim HY, Yokozawa T (2007) Effect of sun ginseng methanol extract on lipopolysaccharide-induced liver injury in rats. Phytomedicine 14(12):840-845
86. Yokozawa T, Kang KS, Yamabe N, Kim HY (2007) Therapeutic potential of heat-processed Panax ginseng with respect to oxidative tissue damage. Drug Discov Therapeut 1(1):30-44

87. Waheed RM, Bakery HH, El-Shawarby RM, Abou Salem ME (2011) Toxicity of Lambda cyhalothrine on erythrogram,liver and kidney with molorated by vitamine c. Benha Vet Med J 22(2):238-248

88. Fadina OO, Oshoke Fl, Fayinminnu OO (2017) Toxicity assessment of synthetic pyrethroids (Lambda Cyhalothrin) on the liver and kidney organs of male Wistar rats. Annu. Res. Rev. Biol. 13(6):1-7

89. Basir A, Khan A, Mustafa R, Khan MZ, Rizvi F, Mahmood F, Yousaf A (2011) Toxicopathological effects of lambda-cyhalothrin in female rabbits (Oryctolagus cuniculus). Hum Exp Toxicol:591-602

90. El-Bendary HM, Negm SE, Saleh AA, Kady MM, Hosam Eldeen FA (2010) Histopathological changes associated with exposure of male mice to pyrethroid pesticide (lambda-cyhalothrin). J. Plant Protection and Pathology Mansoura Univ. (9):697-710

91. Al-Sarar AS, Abobakr Y, Bayoumi AE, Hussein HI, Al-Ghothemi M (2012) Reproductive toxicity and histopathological changes induced by Lambdacyhalothrin in male mice. Environ Toxicol:750: 762

92. Mossa AH, Heikal TM, Belaiba M, Raoelison EG, Ferhout H, Bouajila J (2015) Antioxidant activity and hepatoprotective potential of Cedrelopsis grevei on cypermethrin induced oxidative stress and liver damage in male mice. BMC Complement. Alternat Med 15(251):1-10

93. Abdul-Hamid M, Moustafa M, Asran AA, Mowafy L (2017) Cypermethrininduced histopathological, ultrastructural and biochemical changes in liver of albino rats: The protective role of propolis and curcumin. Beni- suef Univ J Appl Sci 6(2):160-173

94. Khan A, Faridi HAM, Ali M, Khan MZ, Siddique M, Hussain I, Ahmad M (2009) Effects of cypermethrin on some clinico-hemato-biochemical and pathological parameters in male dwarf goats (Capra hircus). Exp Toxicologic Pathol 61(2):151-160

95. Luty S, Latuszynska J, Hanina H, Tochman A, Obuchowska D, Przylepa E, Korczak E, Bychawski E (1998) Toxicity of dermally absorbed dichlorvos in rats. Ann Agric Environ Med 5:57-64

96. Luty S, Latuszynska J, Hanina H, Tochman A, Obuchowska D, Przebirowska D, Tokarska M, Haratym-Maj A (2000) Subacute toxicity of orally applied alpha-cypermethrin in Swiss mice. Ann Agric Environ Med 7:33-41

97. Guzelian PS, Qureshi GD, Gelmann RD (1981) Collagen synthesis by the hepatocyte: studies in primary cultures of parenchymal cells from adult rat liver. Coll Res 1:83-93

\section{Publisher's Note}

Springer Nature remains neutral with regard to jurisdictional claims in published maps and institutional affiliations.

\section{Submit your manuscript to a SpringerOpen ${ }^{\circ}$ journal and benefit from:}

- Convenient online submission

- Rigorous peer review

- Open access: articles freely available online

High visibility within the field

- Retaining the copyright to your article

Submit your next manuscript at $>$ springeropen.com 